\title{
Supplementary Data for
}

\section{"Click chemistry" Inspired Synthesis of pseudo-Oligosaccharides and Amino Acid Glycoconjugates}

\author{
Srinivas Hotha* and Sudhir Kashyap
}

Combi Chem - Bio Resource Center, Division of Organic Chemistry: Synthesis National Chemical Laboratory, Pune -411008 , India

\section{s.hotha@ncl.res.in}

\section{Contents}

$\begin{array}{lc} & \begin{array}{c}\text { Page } \\ \text { Number }\end{array} \\ \text { Abstract } & \mathrm{S} 2 \\ \text { General Experimental Techniques } & \mathrm{S} 2 \\ { }^{1} \mathrm{H},{ }^{13} \mathrm{C} \text { and DEPT NMR Spectral Charts of Compound } \mathbf{4} & \mathrm{S} 3 \\ { }^{1} \mathrm{H},{ }^{13} \mathrm{C} \text { and DEPT NMR Spectral Charts of Compound } \mathbf{5} & \mathrm{S} 4 \\ { }^{1} \mathrm{H},{ }^{13} \mathrm{C} \text { and DEPT NMR Spectral Charts of Compound } \mathbf{6} & \mathrm{S} 5 \\ { }^{1} \mathrm{H},{ }^{13} \mathrm{C} \text { and DEPT NMR Spectral Charts of Compound } \mathbf{7} & \mathrm{S} 6 \\ { }^{1} \mathrm{H},{ }^{13} \mathrm{C} \text { and DEPT NMR Spectral Charts of Compound } \mathbf{8} & \mathrm{S} 7 \\ { }^{1} \mathrm{H},{ }^{13} \mathrm{C} \text { and DEPT NMR Spectral Charts of Compound } \mathbf{1 0} & \mathrm{S} 8 \\ { }^{1} \mathrm{H},{ }^{13} \mathrm{C} \text { and DEPT NMR Spectral Charts of Compound } \mathbf{1 1} & \mathrm{S} 9 \\ { }^{1} \mathrm{H},{ }^{13} \mathrm{C} \text { and DEPT NMR Spectral Charts of Compound } \mathbf{1 2} & \mathrm{S} 10 \\ { }^{1} \mathrm{H},{ }^{13} \mathrm{C} \text { and DEPT NMR Spectral Charts of Compound } \mathbf{1 3} & \mathrm{S} 11 \\ { }^{1} \mathrm{H},{ }^{13} \mathrm{C} \text { and DEPT NMR Spectral Charts of Compound } \mathbf{1 4} & \mathrm{S} 12 \\ { }^{1} \mathrm{H},{ }^{13} \mathrm{C} \text { and DEPT NMR Spectral Charts of Compound } \mathbf{1 5} & \mathrm{S} 13 \\ { }^{1} \mathrm{H},{ }^{13} \mathrm{C} \text { and DEPT NMR Spectral Charts of Compound } \mathbf{1 6} & \mathrm{S} 14 \\ { }^{1} \mathrm{H},{ }^{13} \mathrm{C} \text { and DEPT NMR Spectral Charts of Compound } \mathbf{1 7} & \mathrm{S} 15 \\ { }^{1} \mathrm{H},{ }^{13} \mathrm{C} \text { and DEPT NMR Spectral Charts of Compound } \mathbf{1 8} & \mathrm{S} 16 \\ { }^{1} \mathrm{H},{ }^{13} \mathrm{C} \text { and DEPT NMR Spectral Charts of Compound } \mathbf{1 9} & \mathrm{S} 17 \\ { }^{1} \mathrm{H},{ }^{13} \mathrm{C} \text { and DEPT NMR Spectral Charts of Compound } \mathbf{2 0} & \mathrm{S} 18 \\ { }^{1} \mathrm{H},{ }^{13} \mathrm{C} \text { and DEPT NMR Spectral Charts of Compound } \mathbf{2 1} & \mathrm{S} 19\end{array}$




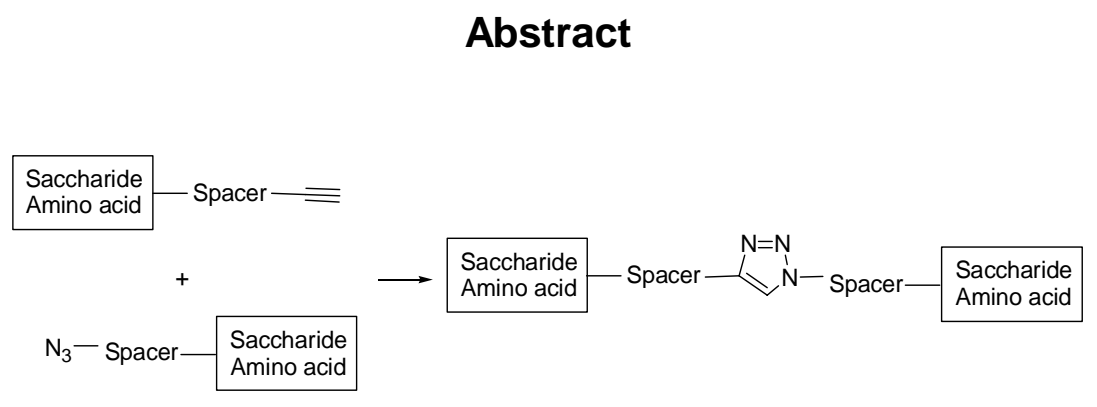

Various pseudo-oligosacchardies and amino acid glycoconjugates were synthesized via an intermolecular 1,3-dipolar cycloaddition ("click") reaction using easily accessible carbohydrate and amino acid derived azides and alkynes as building blocks. It is pertinent to mention that the conjugation reaction was highly regioselective, high yielding and can be carried out under mild reaction conditions.

\section{General Experimental Techniques and Apparatus}

Unless otherwise noted, materials were obtained from commercial suppliers and were used without further purification. Unless otherwise reported all reactions were performed under nitrogen atmosphere. Removal of solvent in vacuo refers to distillation using a rotary evaporator attached to an efficient vacuum pump. Products obtained as solids or syrups were dried under high vacuum. Analytical thin-layer chromatography was performed on pre-coated silica plates $\left(\mathrm{F}_{254}, 0.25 \mathrm{~mm}\right.$ thickness $)$; compounds were visualized by UV light or by staining with anisaldehyde spray. ${ }^{1} \mathrm{H},{ }^{13} \mathrm{C}$ NMR spectra were recorded on $200 \mathrm{MHz}$ for ${ }^{1} \mathrm{H}$ and $50 \mathrm{MHz}$ for ${ }^{13} \mathrm{C}$ NMR or $300 \mathrm{MHz}$ for ${ }^{1} \mathrm{H}$ and 75 $\mathrm{MHz}$ for ${ }^{13} \mathrm{C}$ NMR spectrometers. Chemical shifts $\left(\delta_{\mathrm{H}}\right)$ are quoted in ppm and are referenced to tetramethylsilane (internal). IR spectra were recorded on FT-IR spectrophotometer. 


\section{Spectral Charts}

${ }^{1} \mathrm{H}$ NMR (200 MHz, $\mathrm{CDCl}_{3}$ ) of compound 4

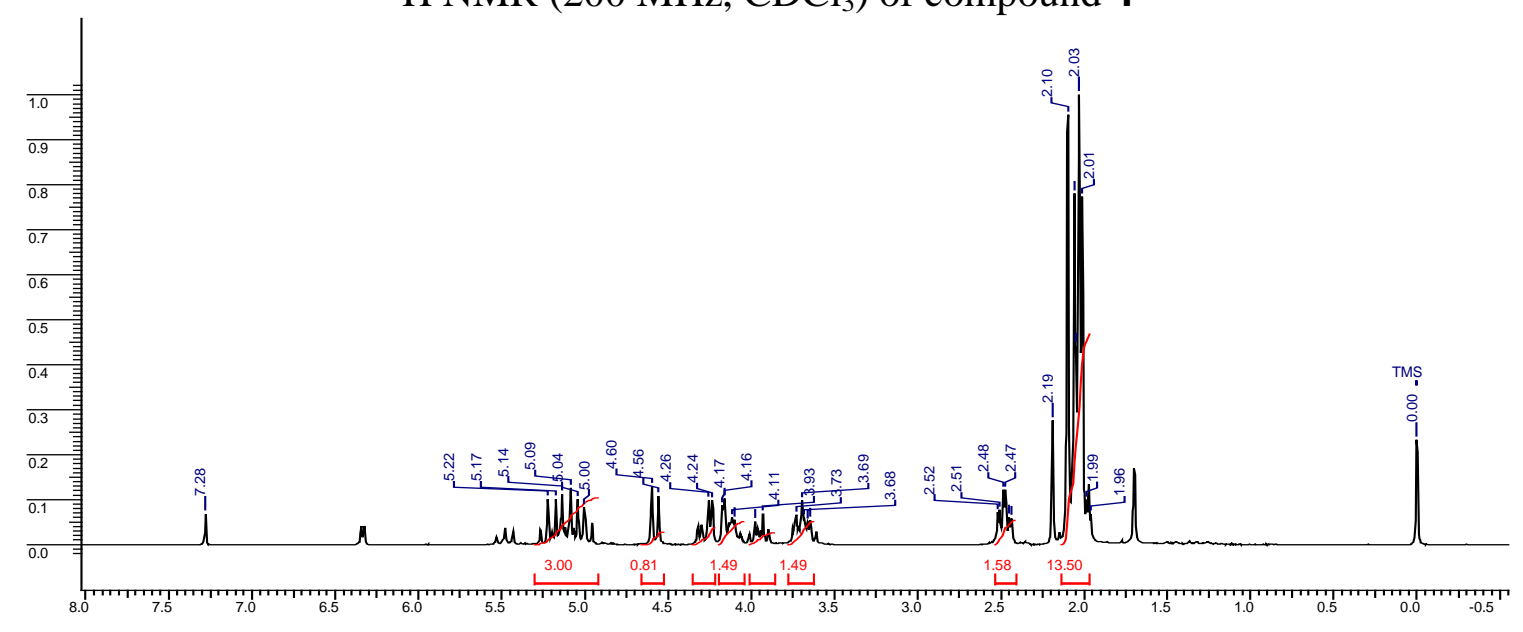

${ }^{13} \mathrm{C}$ NMR (50 MHz, $\mathrm{CDCl}_{3}$ ) of compound 4

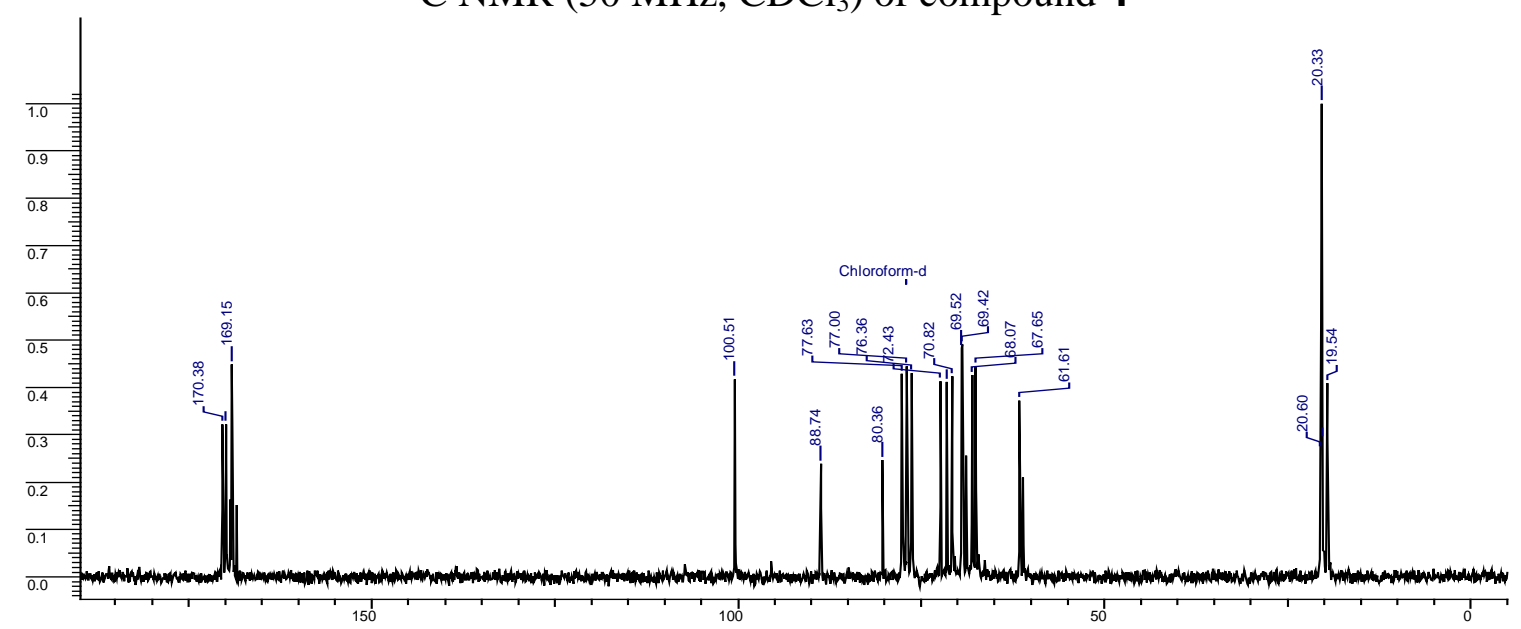

DEPT NMR (50 MHz, $\mathrm{CDCl}_{3}$ ) of compound 4

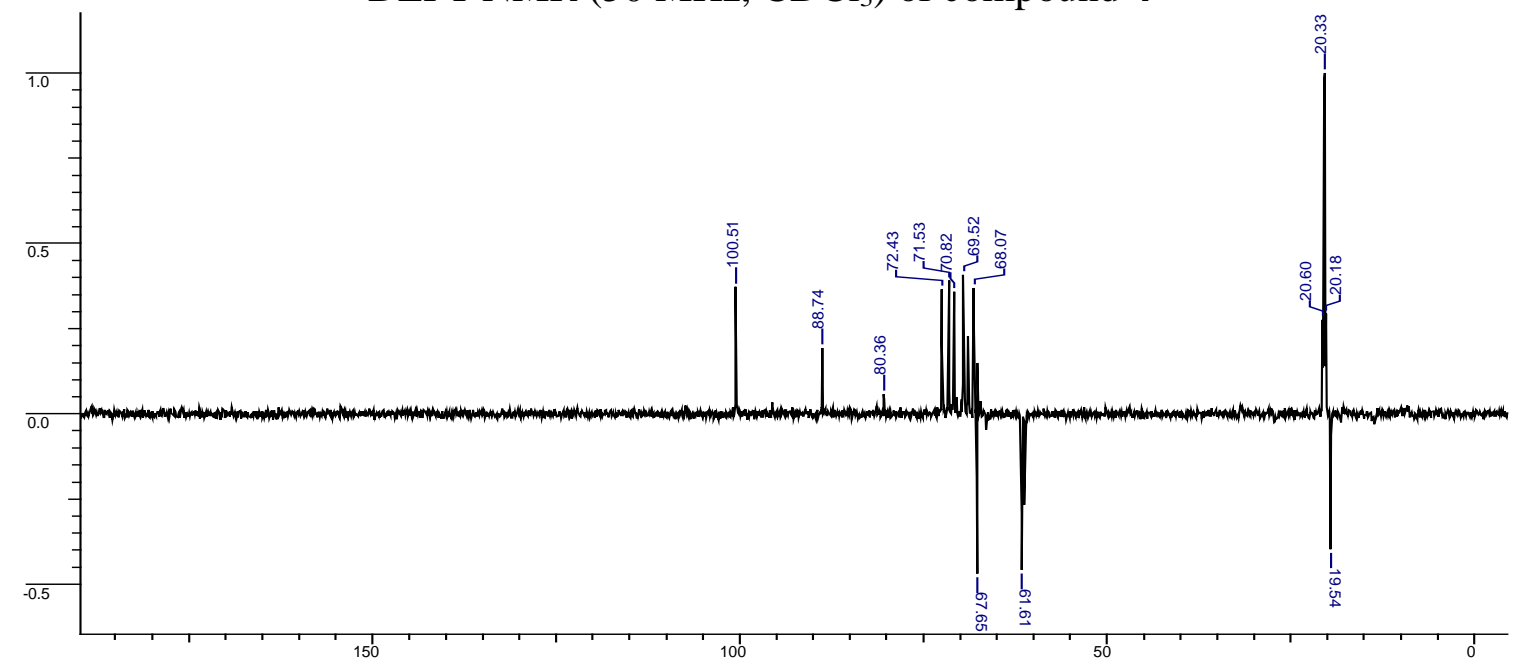


${ }^{1} \mathrm{H}$ NMR (200 MHz, $\mathrm{CDCl}_{3}$ ) of compound $\mathbf{5}$

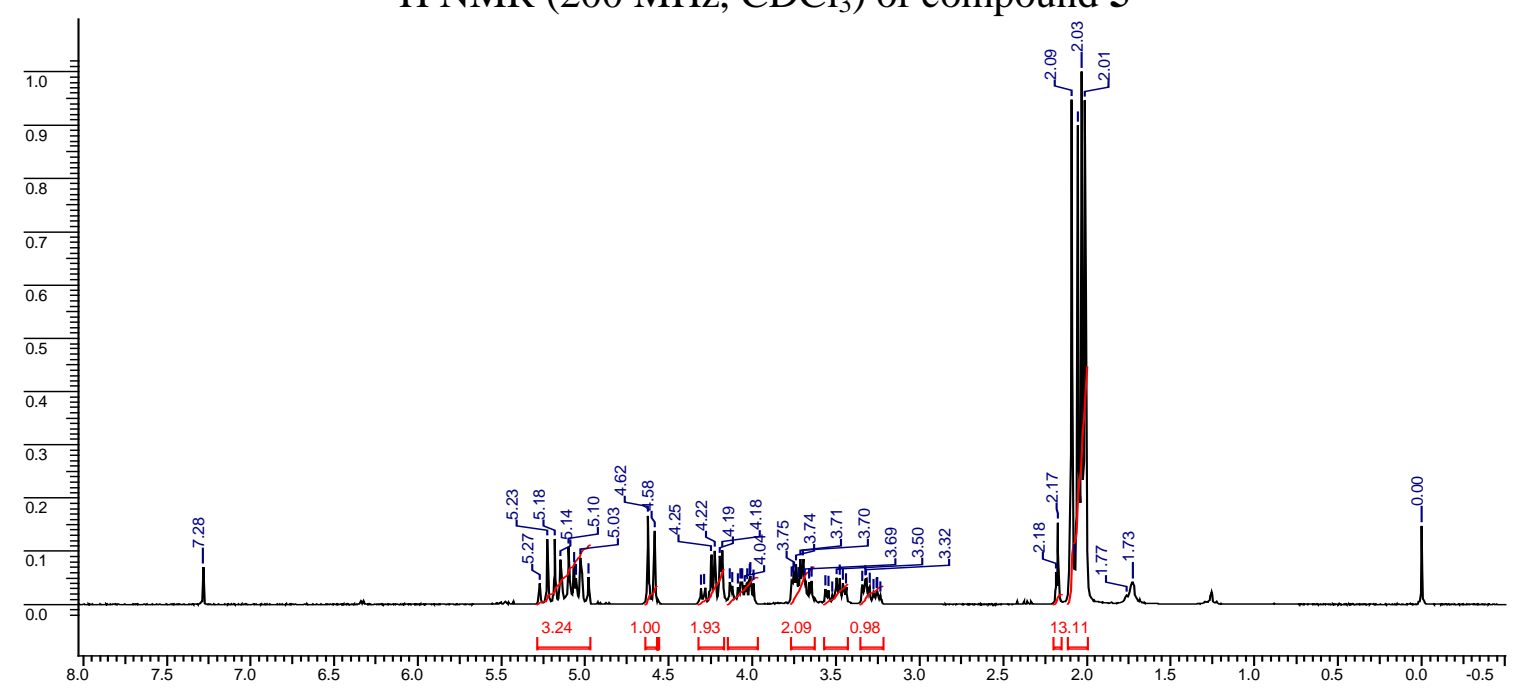

${ }^{13} \mathrm{C}$ NMR (50 MHz, $\mathrm{CDCl}_{3}$ ) of compound 5

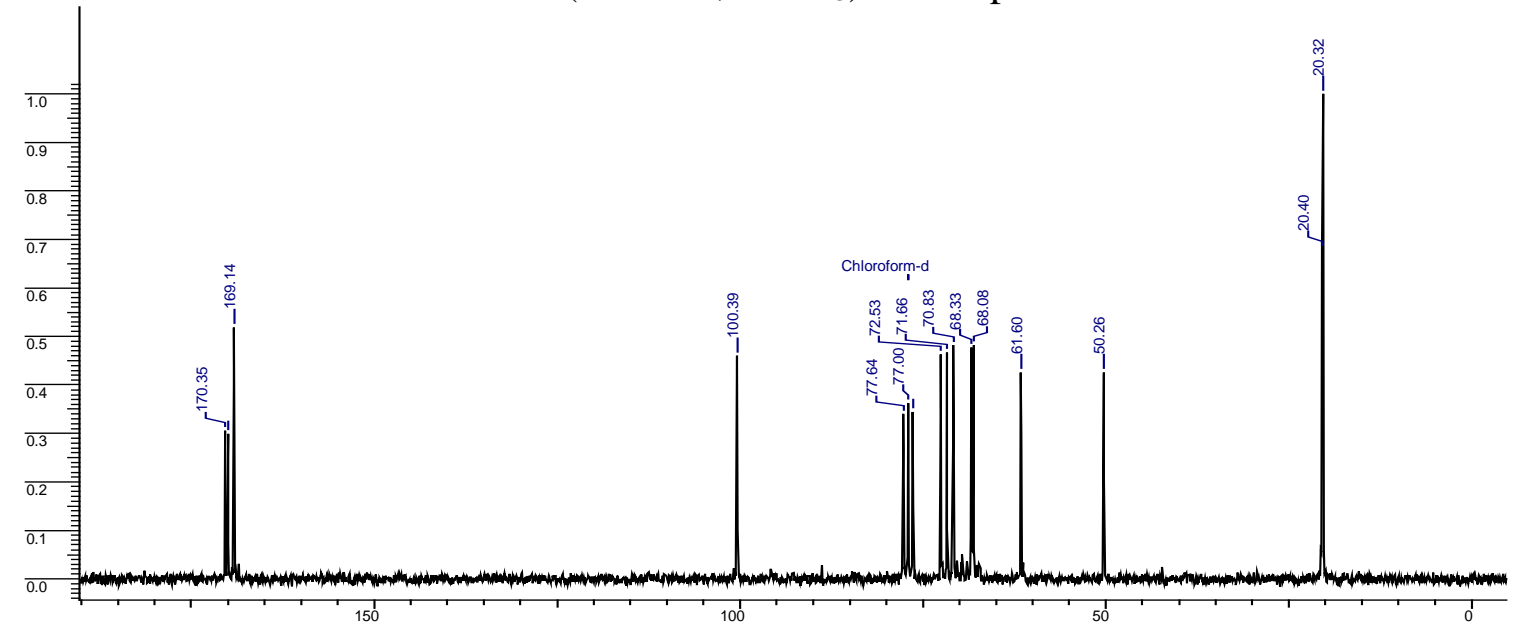

DEPT NMR (50 MHz, $\left.\mathrm{CDCl}_{3}\right)$ of compound 5

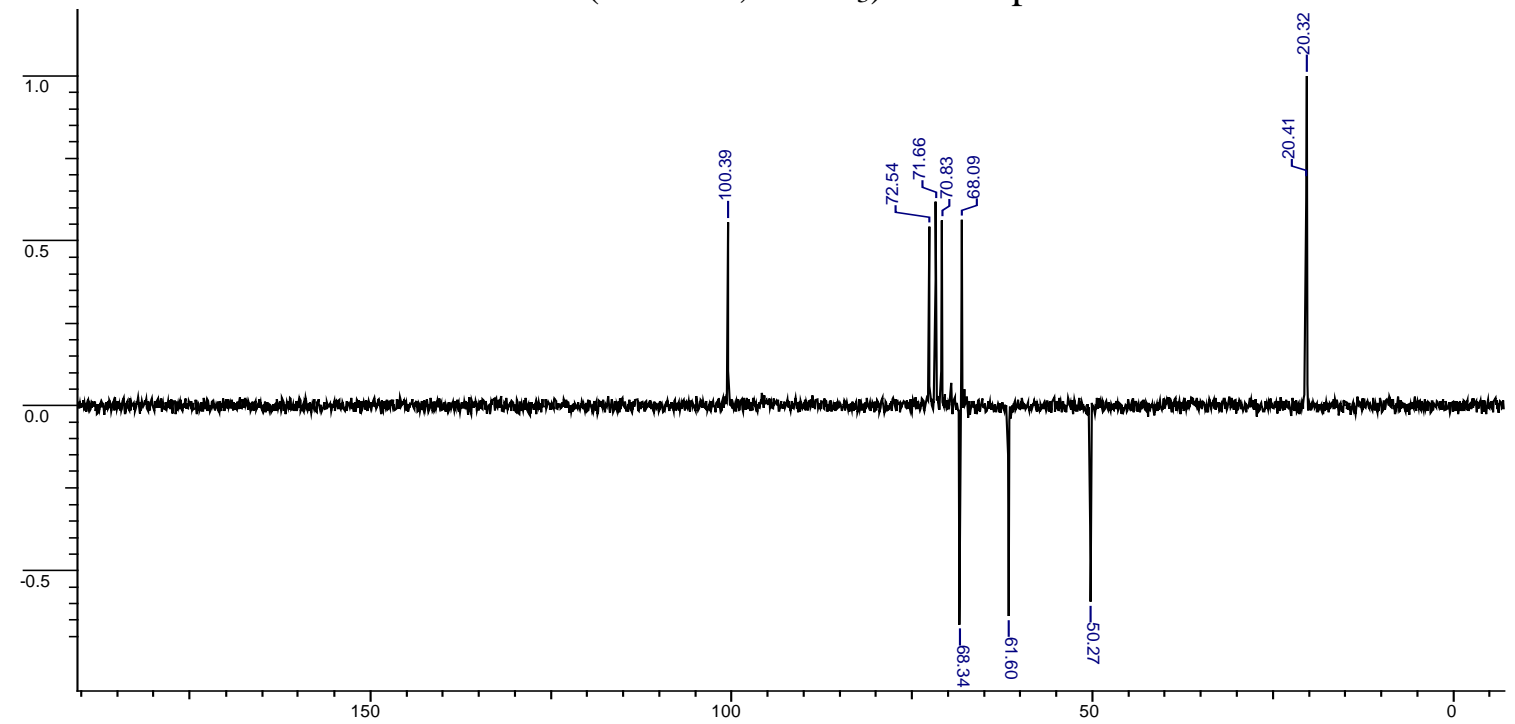


${ }^{1} \mathrm{H}$ NMR $\left(200 \mathrm{MHz}, \mathrm{CDCl}_{3}\right)$ of compound 6

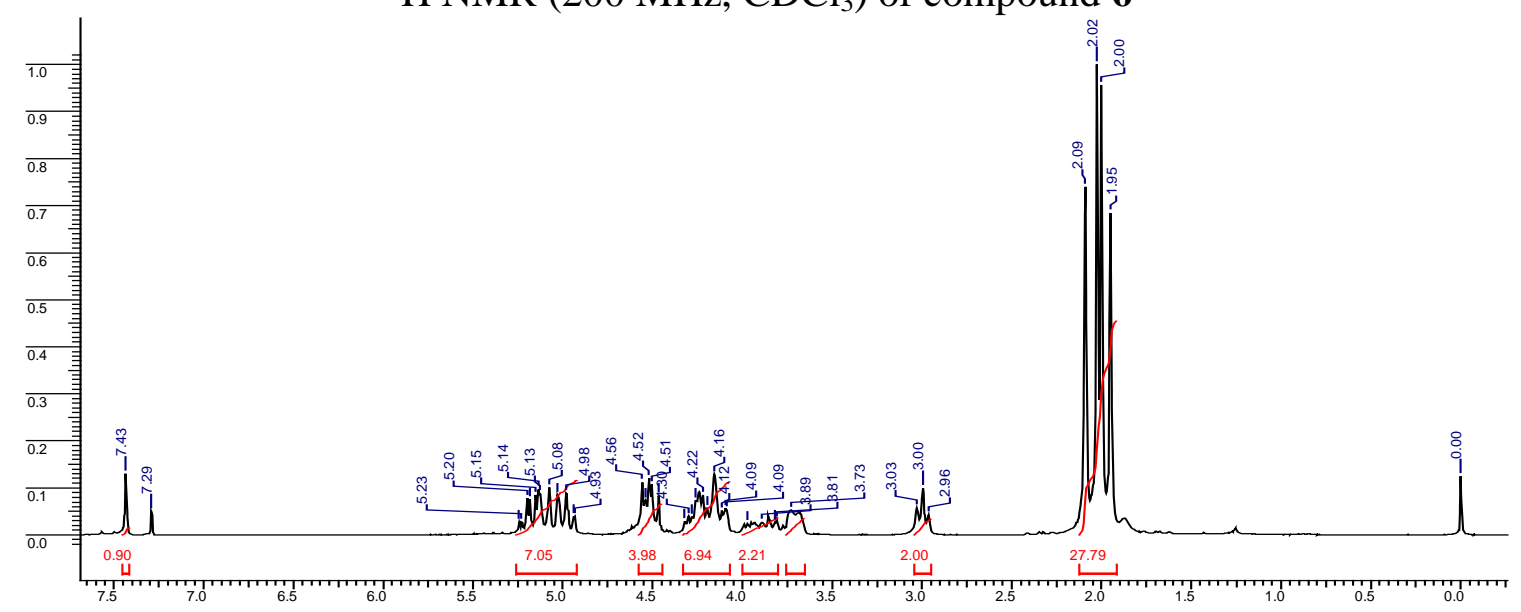

${ }^{13} \mathrm{C}$ NMR (50 MHz, $\mathrm{CDCl}_{3}$ ) of compound 6

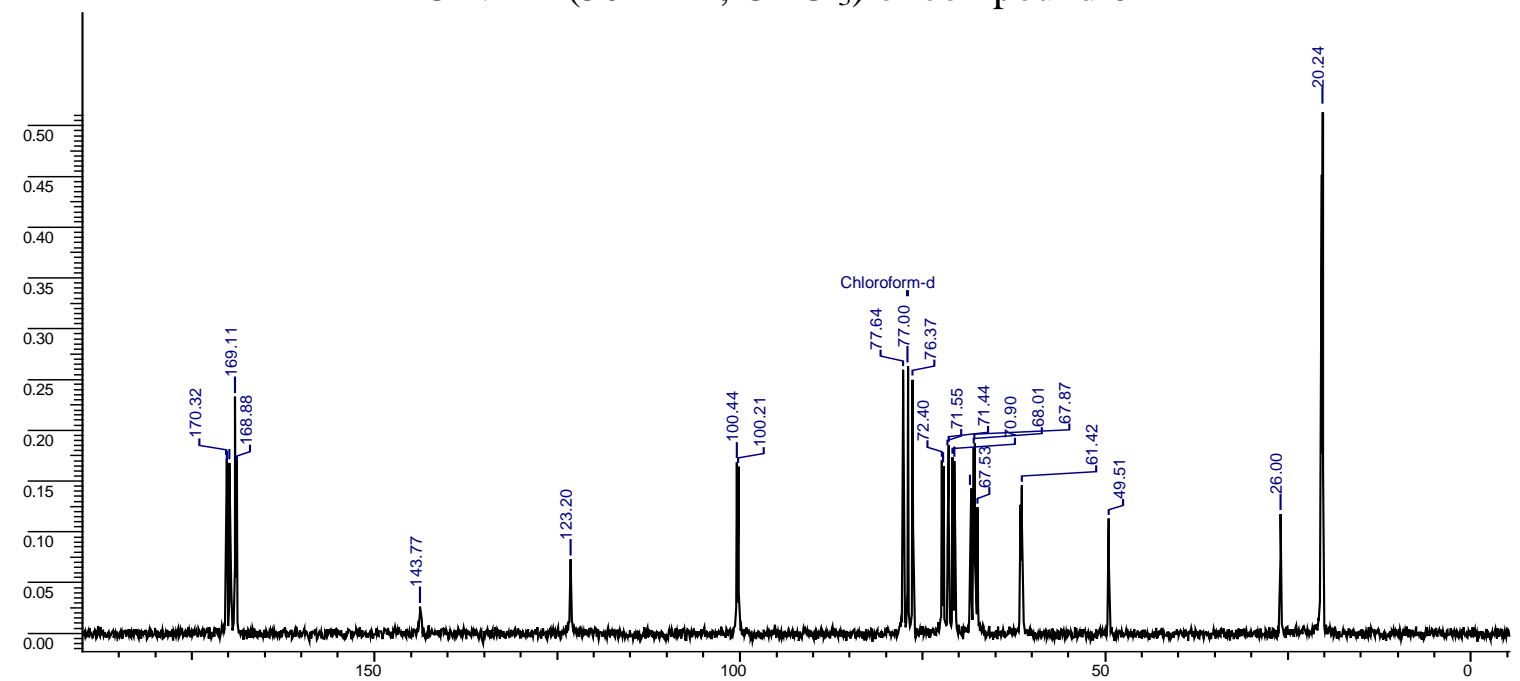

DEPT NMR (50 MHz, $\mathrm{CDCl}_{3}$ ) of compound 6

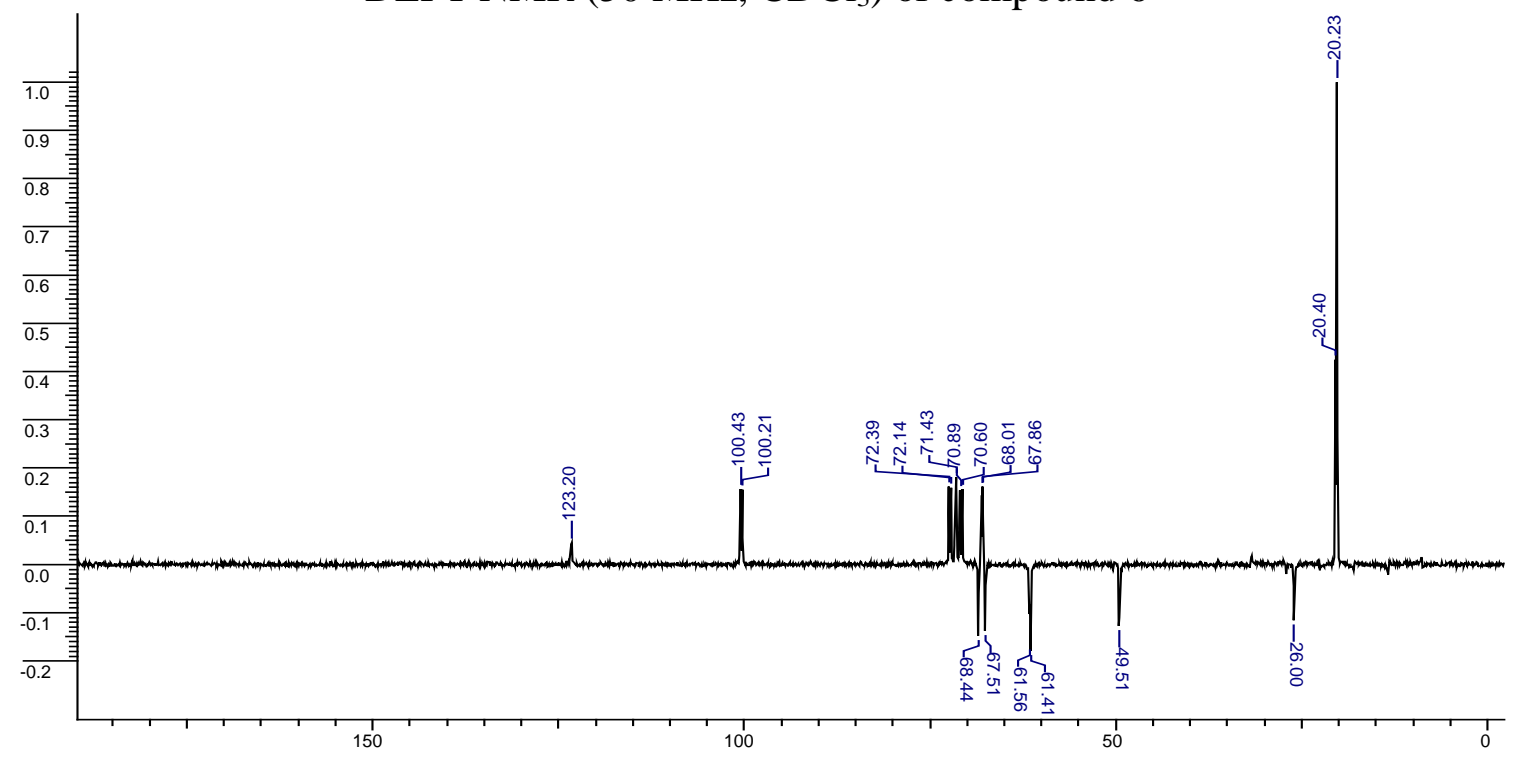


${ }^{1} \mathrm{H}$ NMR (200 MHz, $\mathrm{CDCl}_{3}$ ) of compound 7

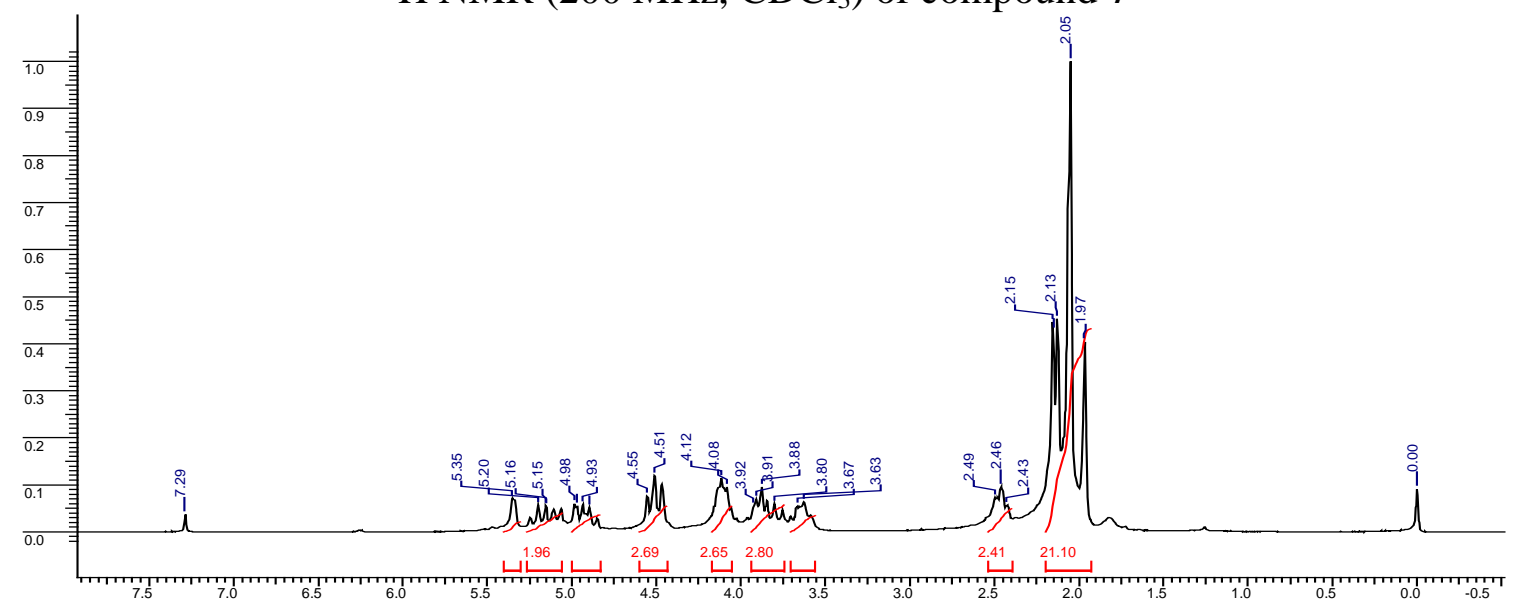

${ }^{13} \mathrm{C}$ NMR (50 MHz, $\mathrm{CDCl}_{3}$ ) of compound 7

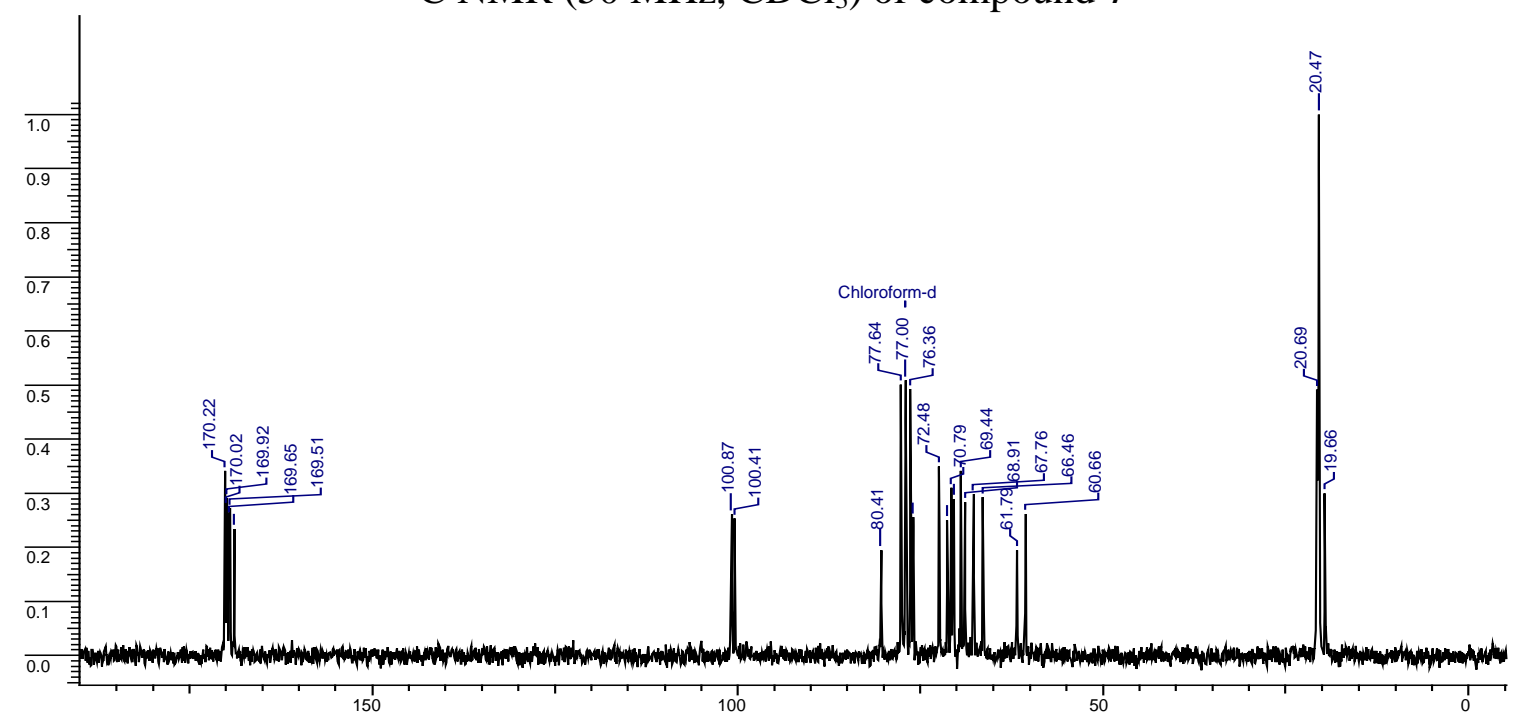

DEPT NMR (50 MHz, $\left.\mathrm{CDCl}_{3}\right)$ of compound 7

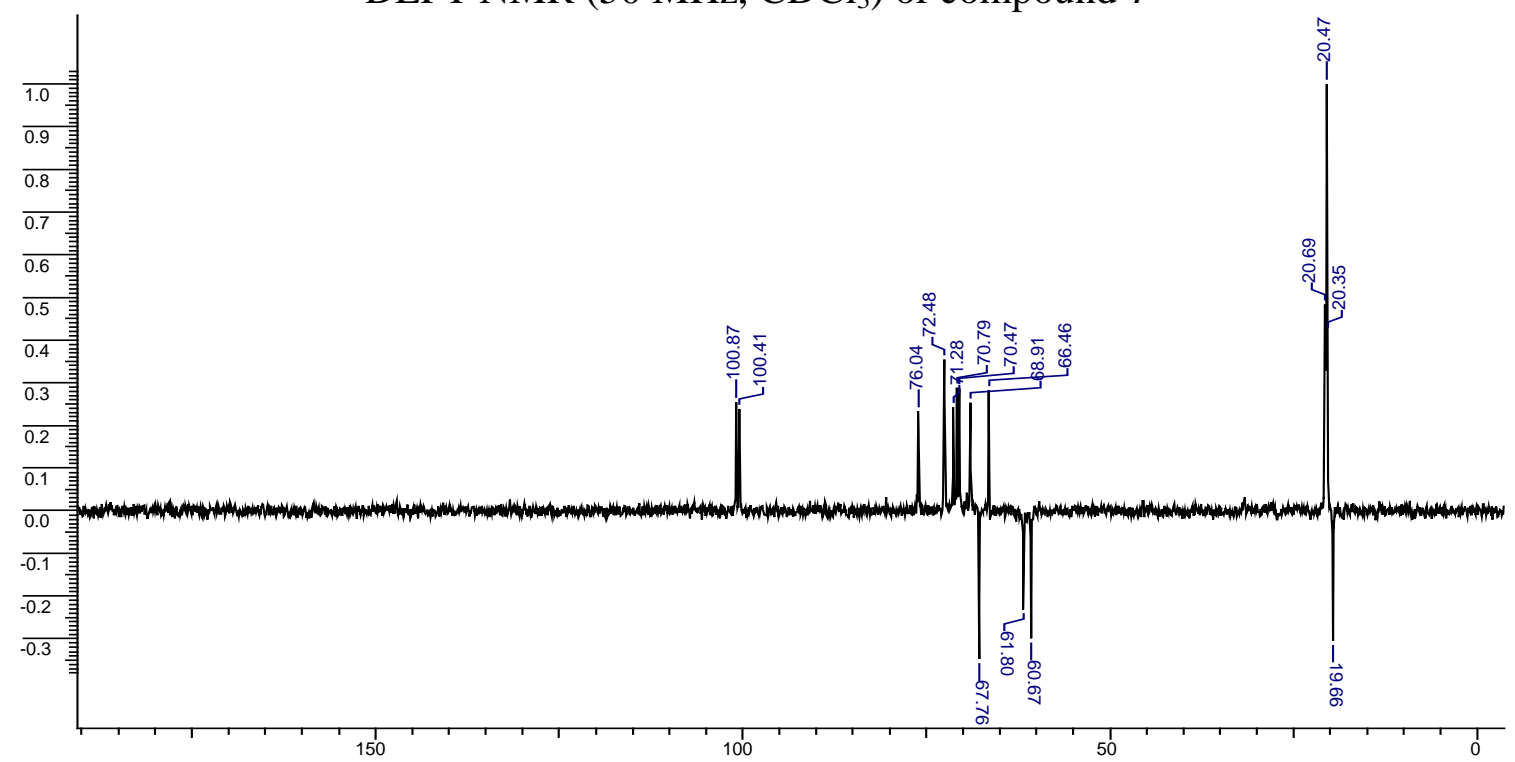


${ }^{1} \mathrm{H}$ NMR (200 MHz, $\mathrm{CDCl}_{3}$ ) of compound 8

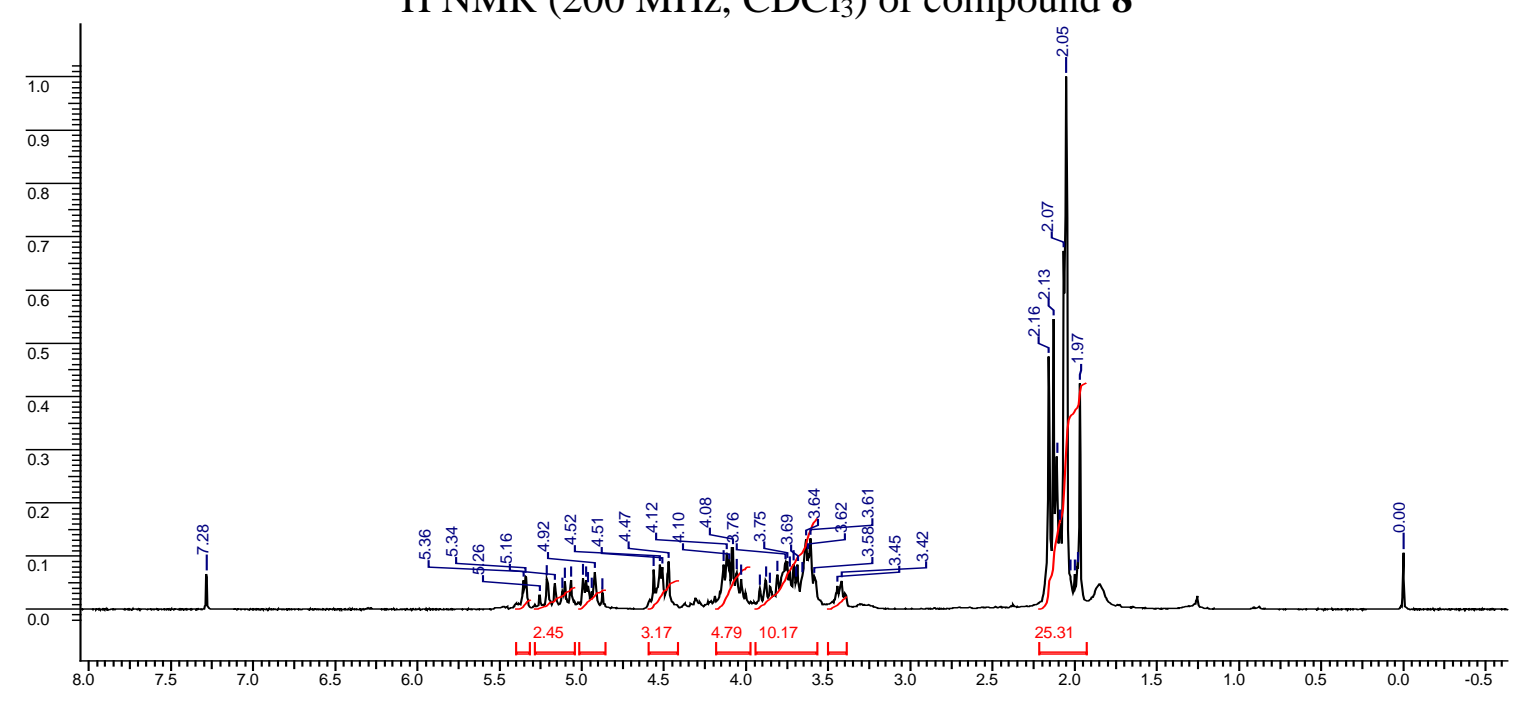

${ }^{13} \mathrm{C}$ NMR $\left(50 \mathrm{MHz}, \mathrm{CDCl}_{3}\right)$ of compound $\mathbf{8}$

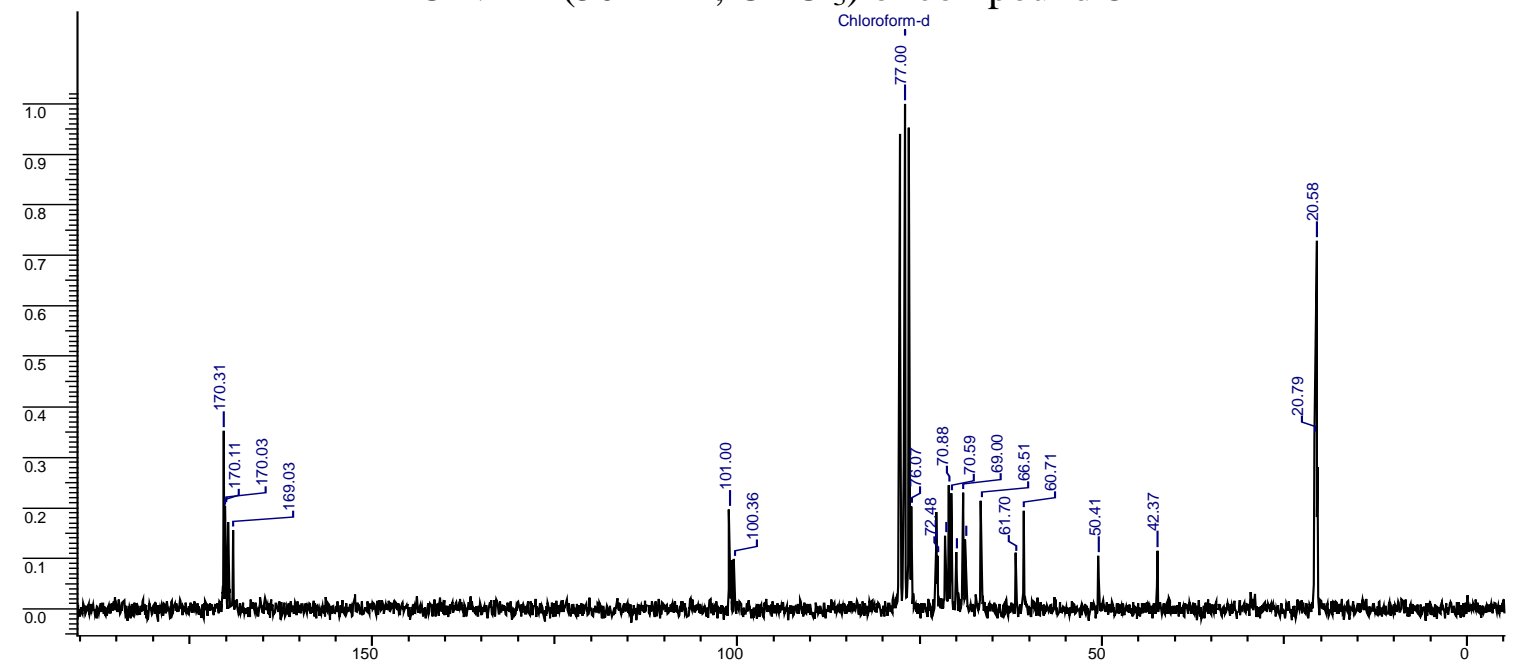

DEPT NMR (50 MHz, $\left.\mathrm{CDCl}_{3}\right)$ of compound $\mathbf{8}$

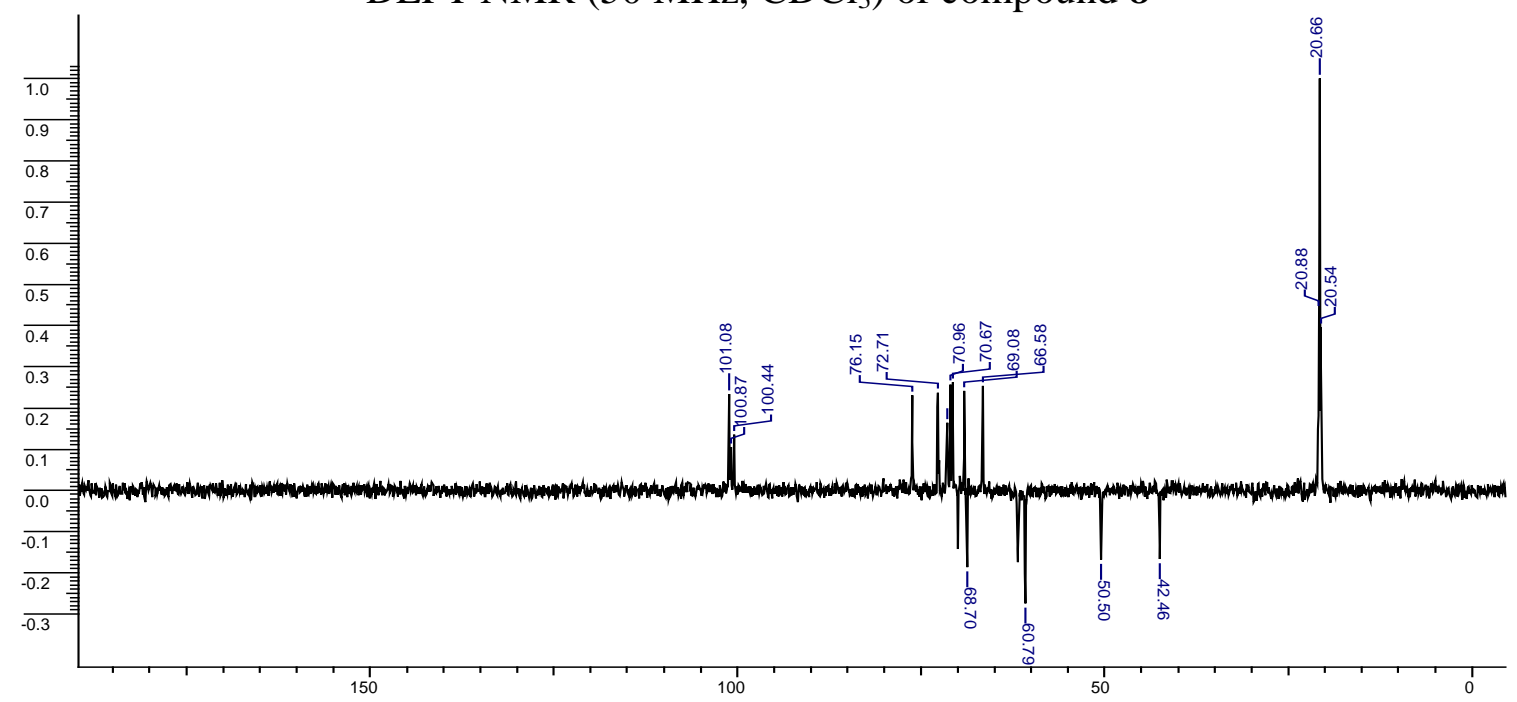


${ }^{1} \mathrm{H}$ NMR $\left(200 \mathrm{MHz}, \mathrm{CDCl}_{3}\right.$ ) of compound $\mathbf{1 0}$

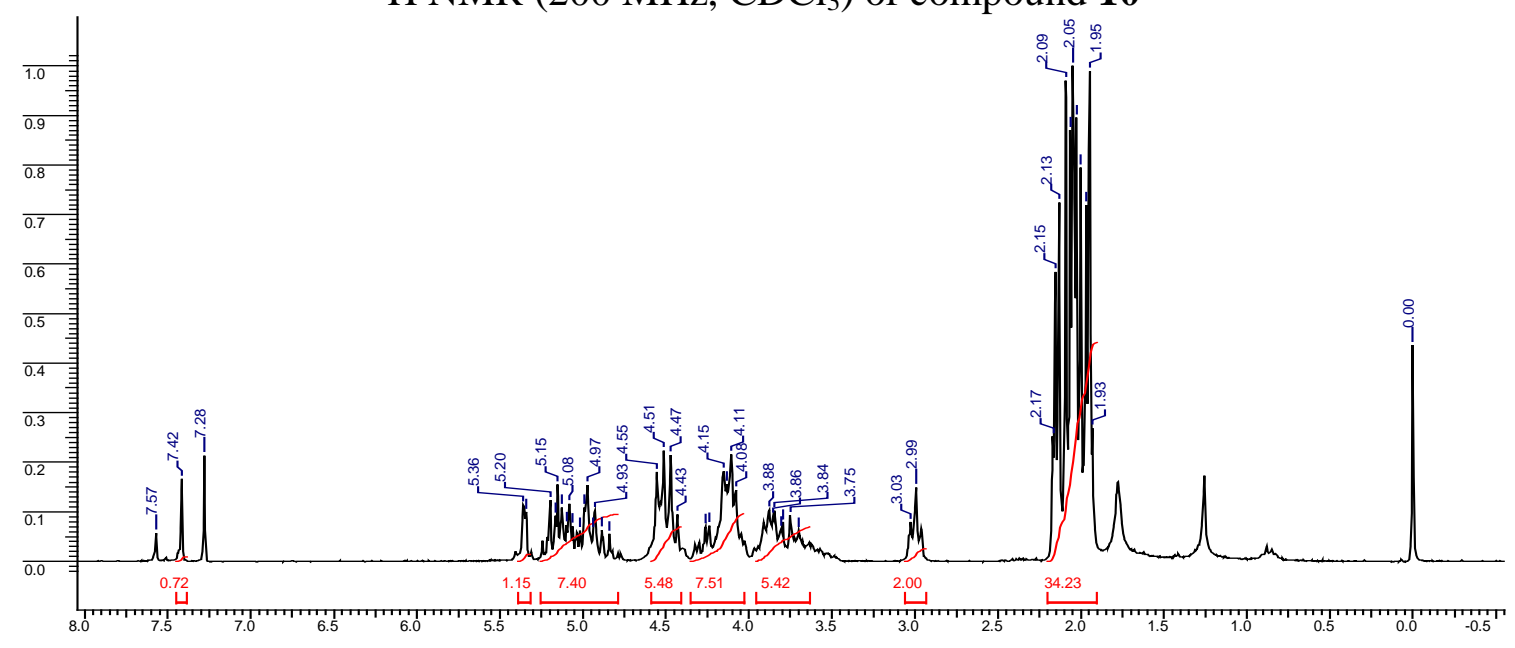

${ }^{13} \mathrm{C}$ NMR (50 MHz, $\mathrm{CDCl}_{3}$ ) of compound 10

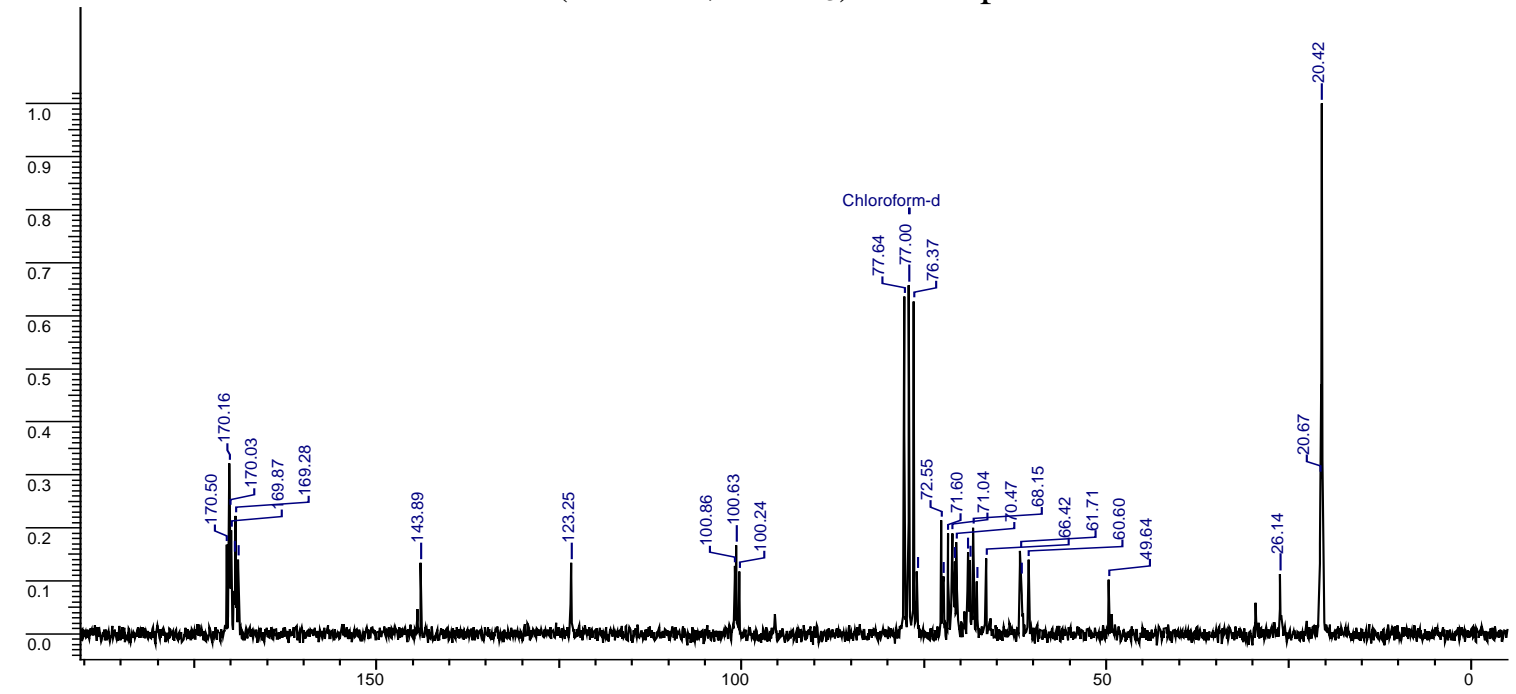

DEPT NMR (50 MHz, $\mathrm{CDCl}_{3}$ ) of compound $\mathbf{1 0}$

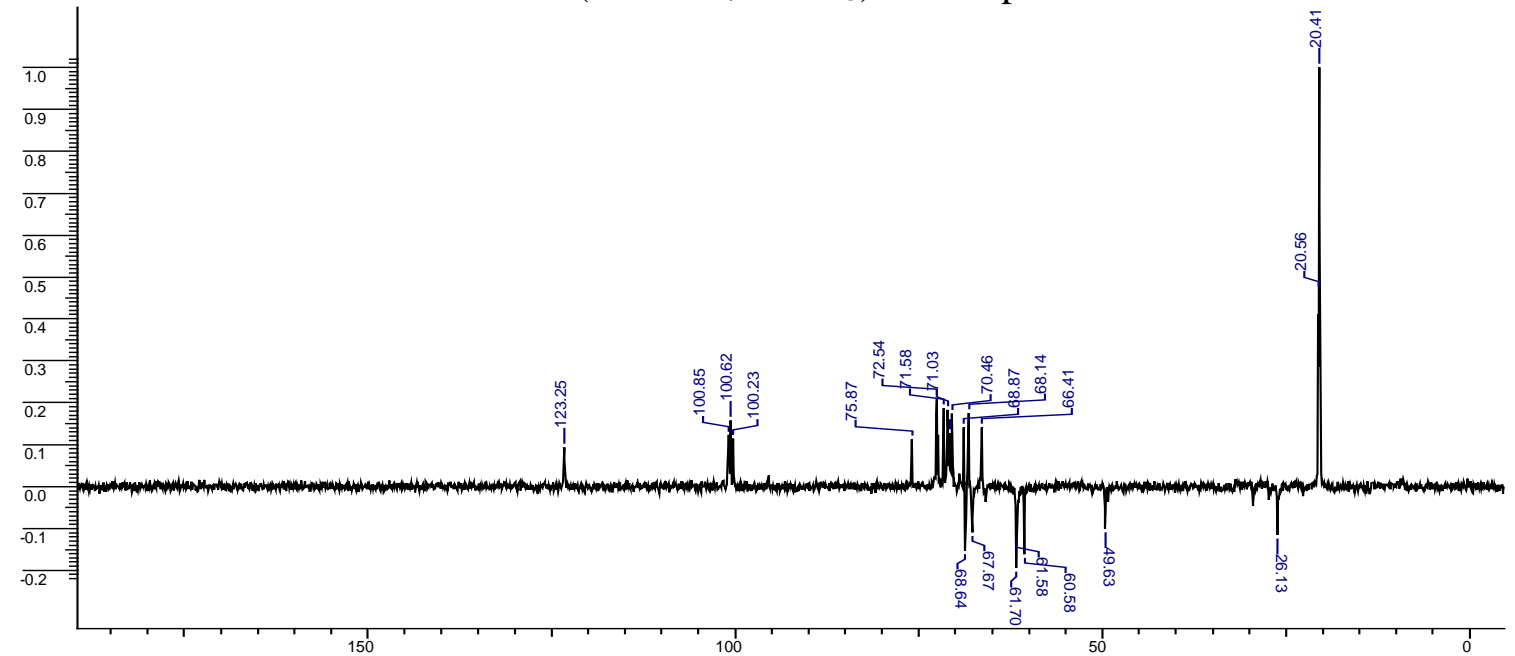


${ }^{1} \mathrm{H}$ NMR (200 MHz, $\mathrm{CDCl}_{3}$ ) of compound 11

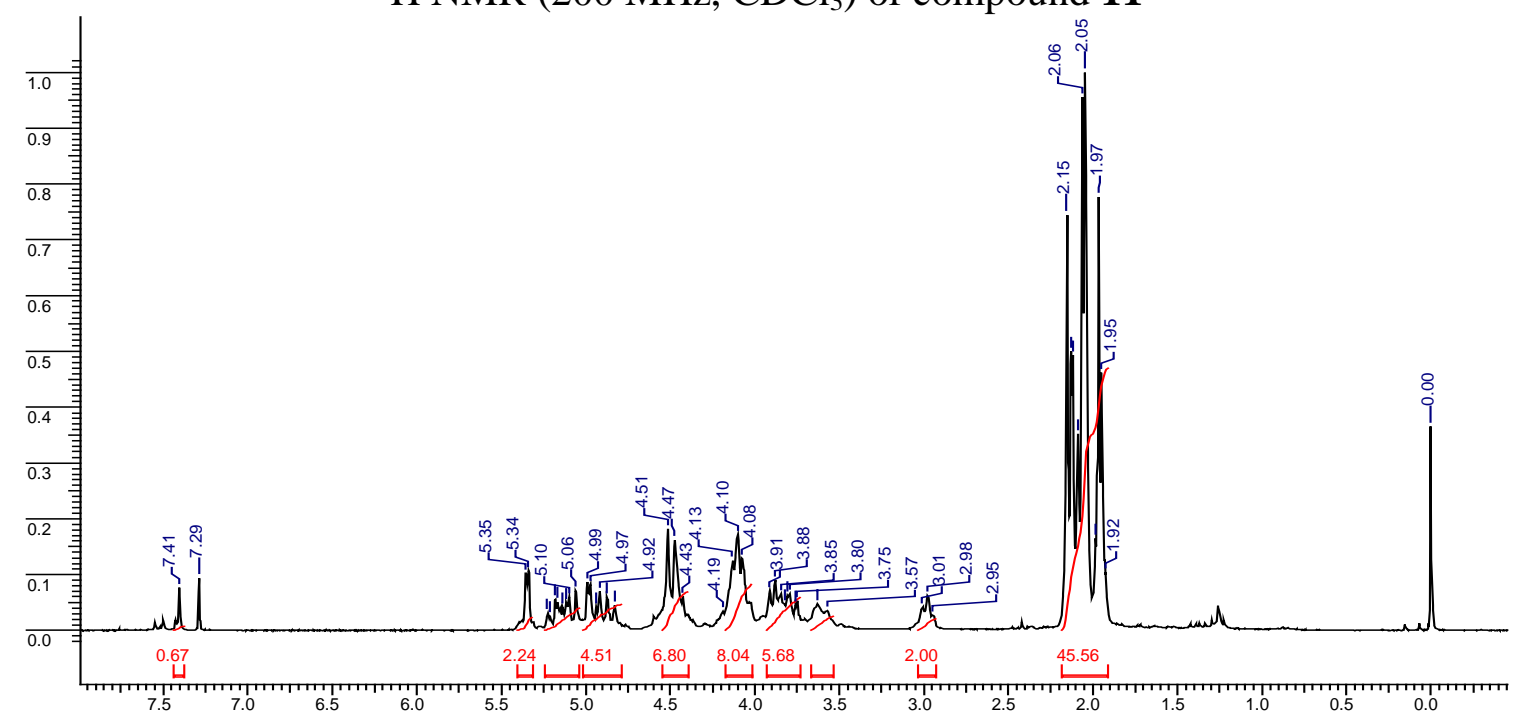

${ }^{13} \mathrm{C}$ NMR (50 MHz, $\mathrm{CDCl}_{3}$ ) of compound 11
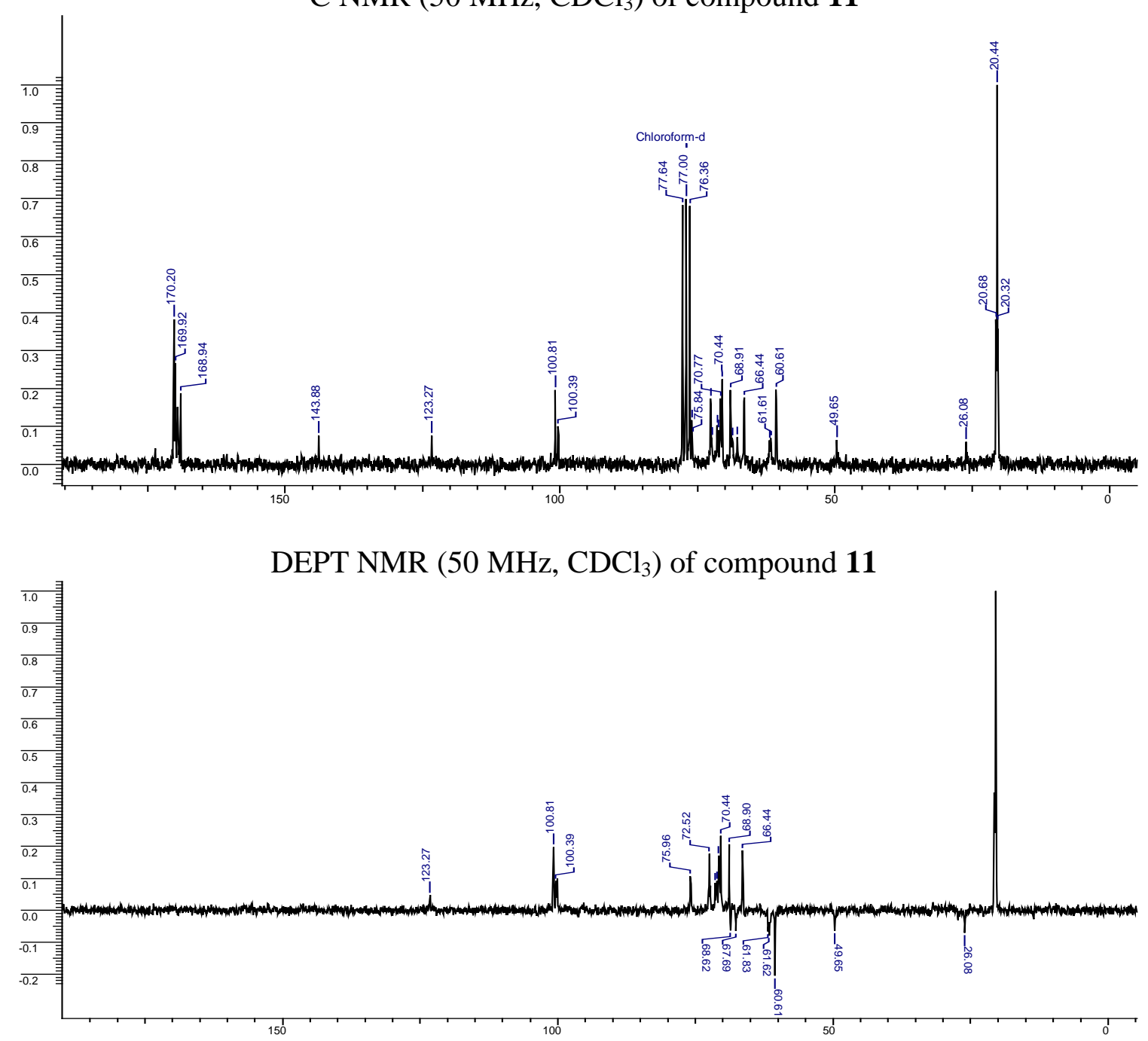
${ }^{1} \mathrm{H}$ NMR (200 MHz, $\mathrm{CDCl}_{3}$ ) of compound 12

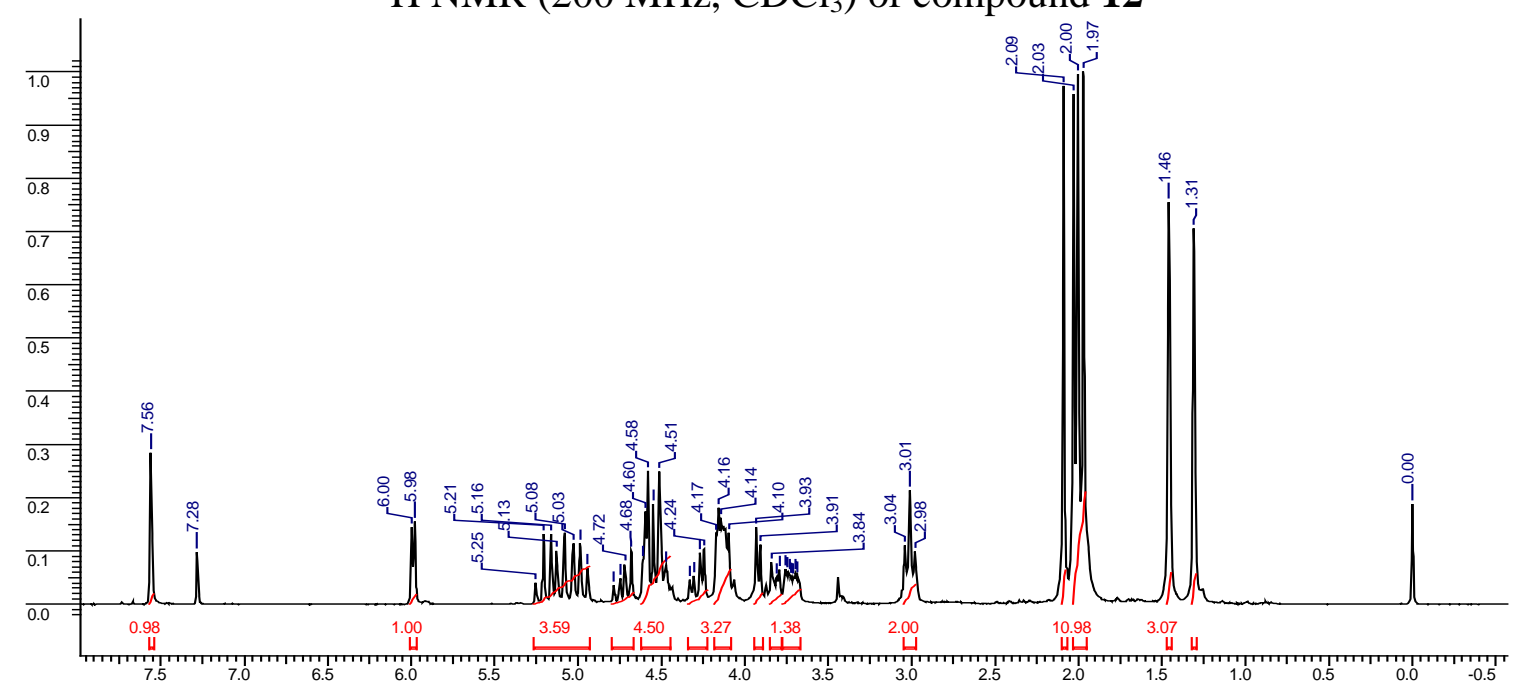

${ }^{13} \mathrm{C}$ NMR (50 MHz, $\mathrm{CDCl}_{3}$ ) of compound 12

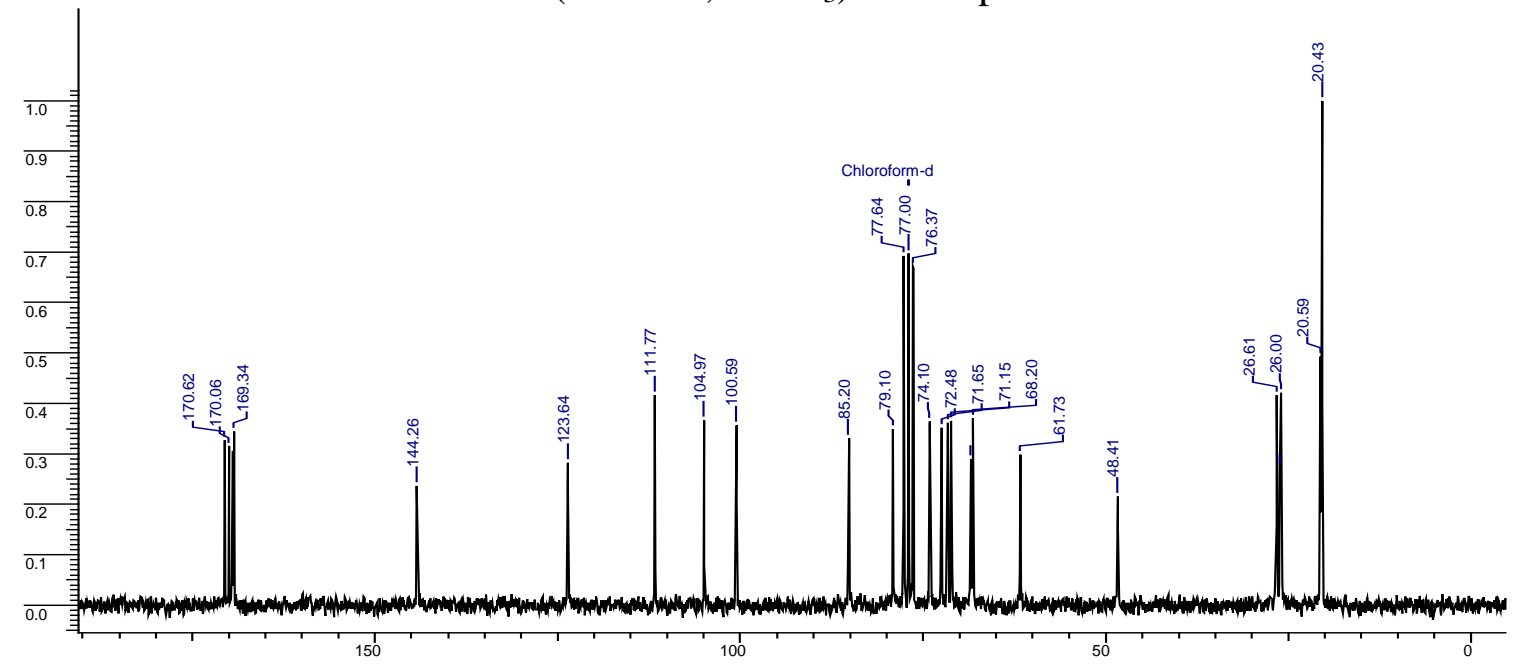

DEPT NMR (50 MHz, $\mathrm{CDCl}_{3}$ ) of compound 12

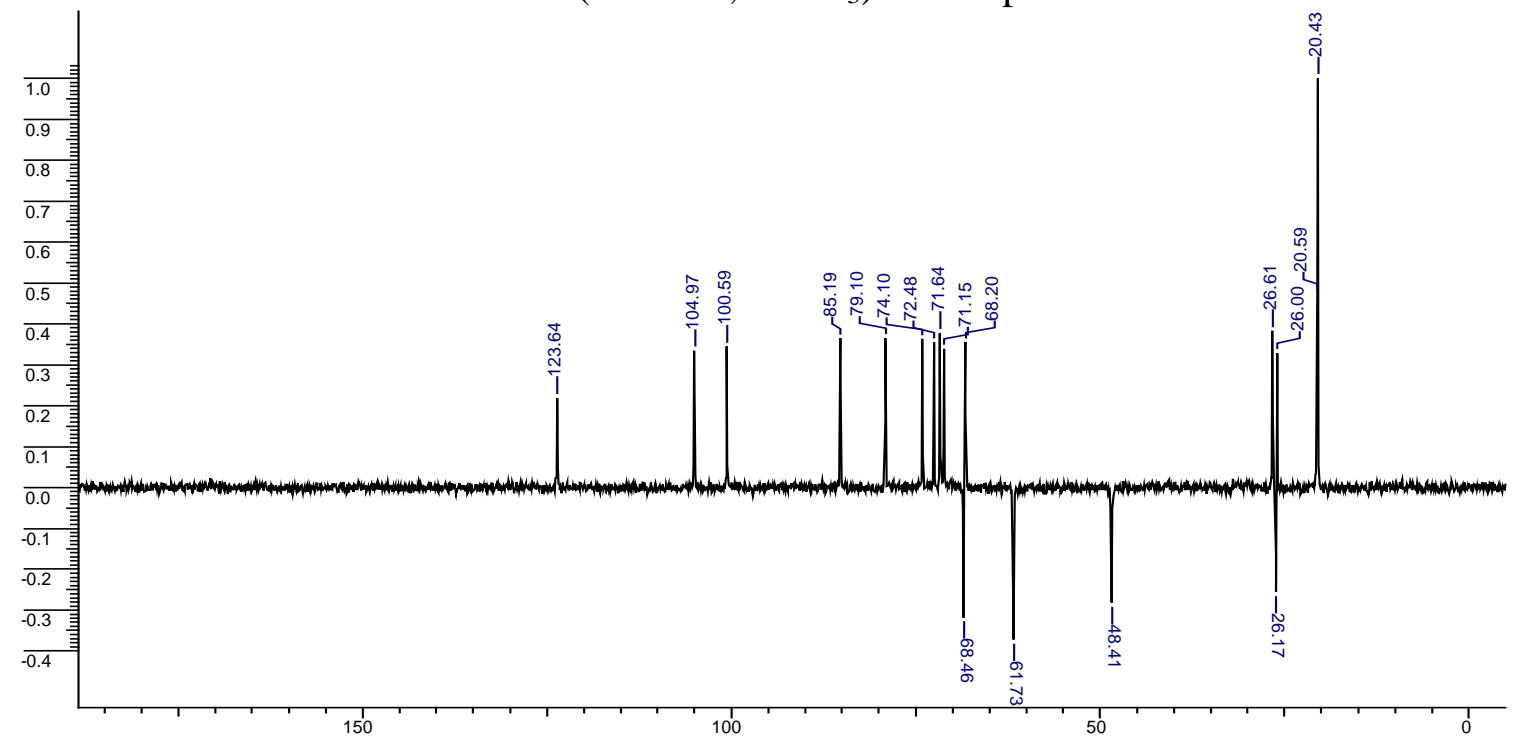


${ }^{1} \mathrm{H}$ NMR (200 MHz, $\mathrm{CDCl}_{3}$ ) of compound 13

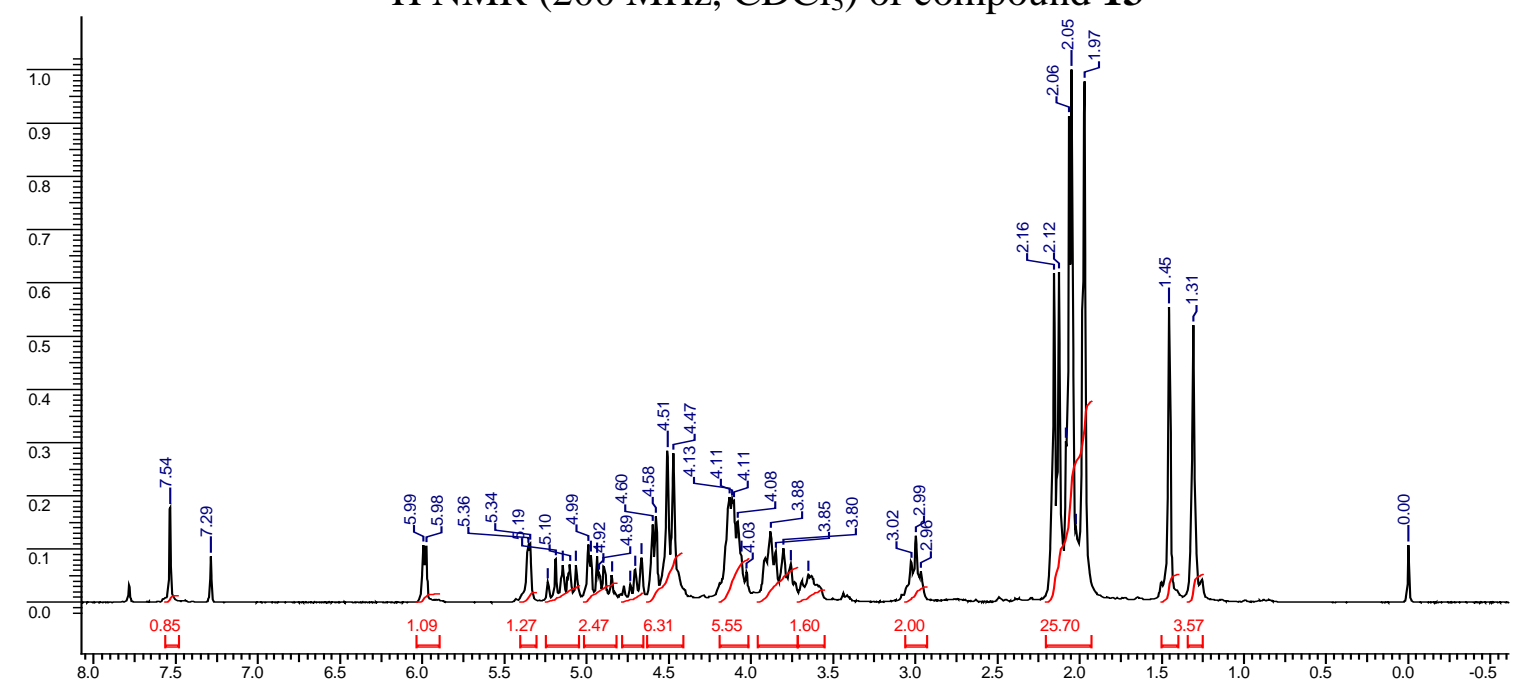

${ }^{13} \mathrm{C}$ NMR (50 MHz, $\mathrm{CDCl}_{3}$ ) of compound 13

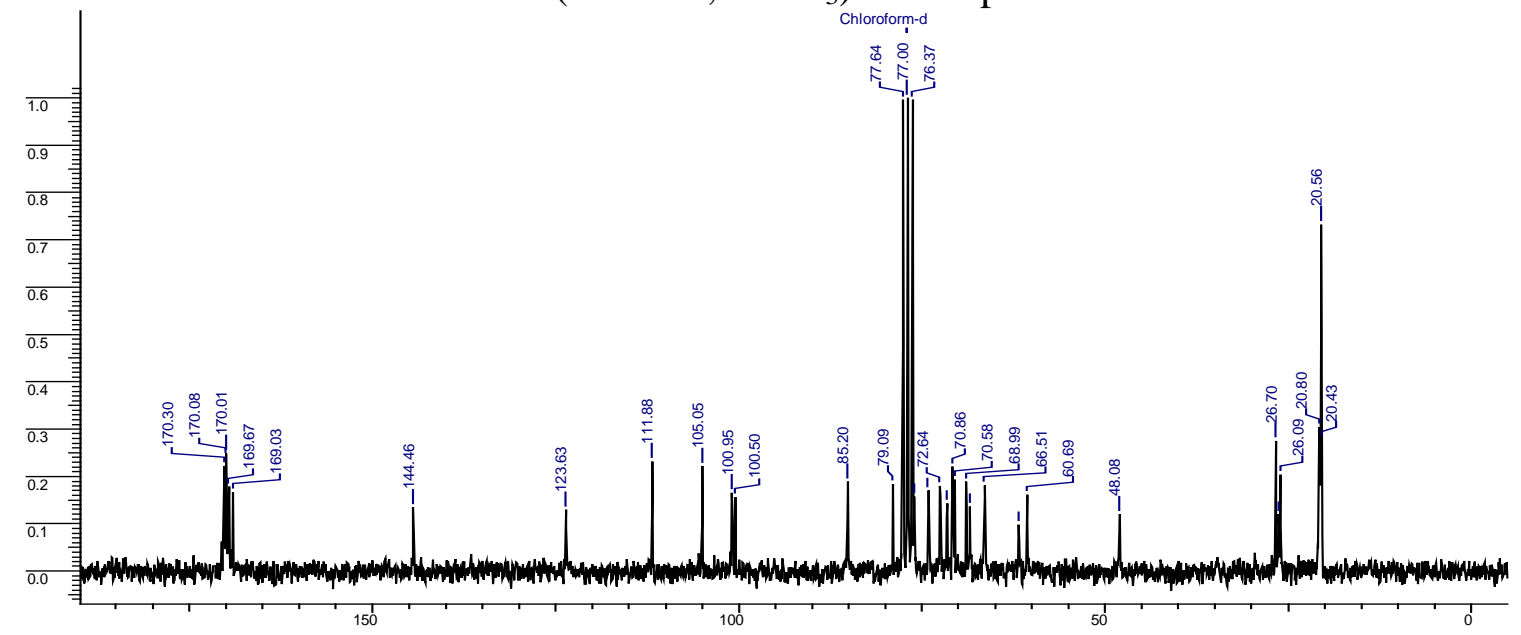

DEPT NMR (50 MHz, $\mathrm{CDCl}_{3}$ ) of compound 13

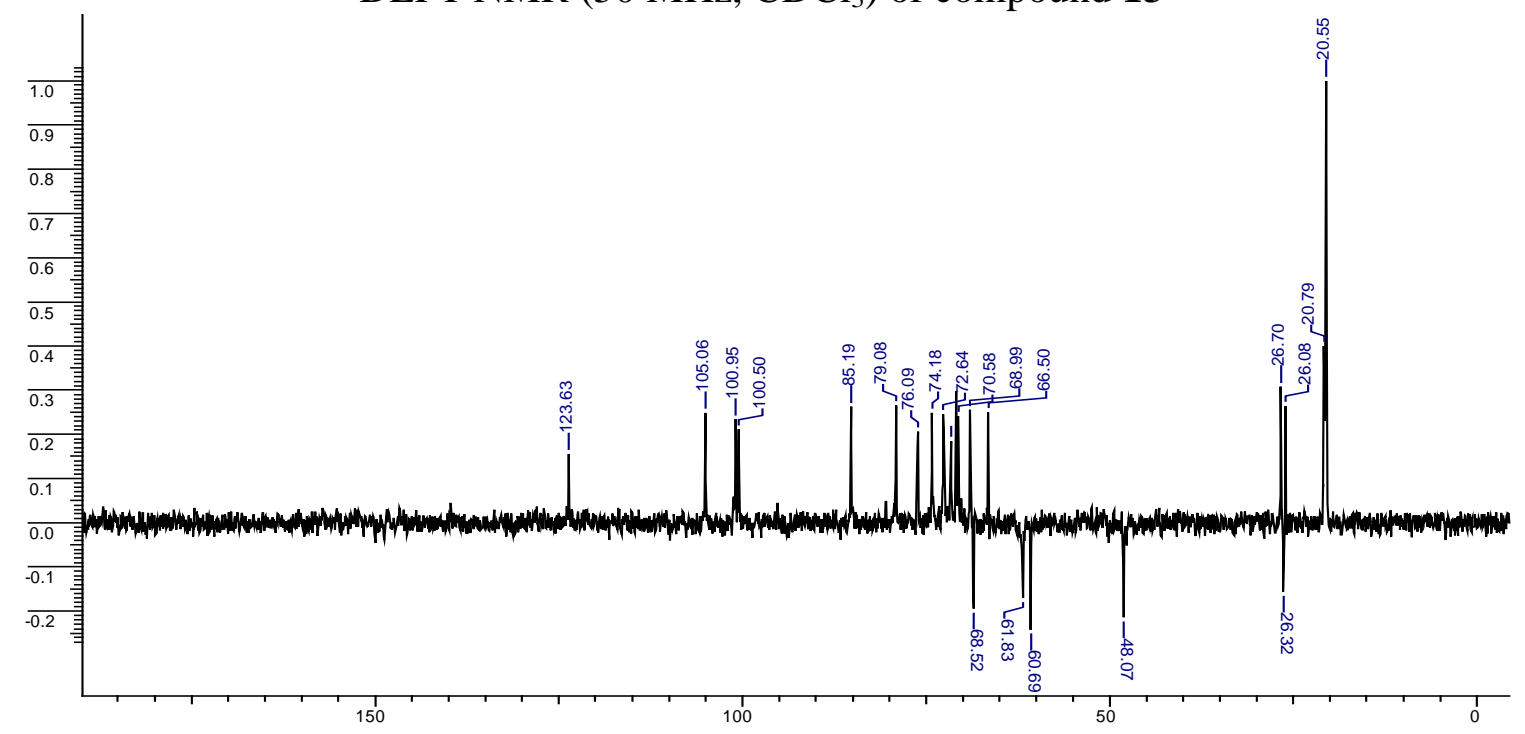


${ }^{1} \mathrm{H}$ NMR (300 MHz, $\mathrm{CDCl}_{3}$ ) of compound 14

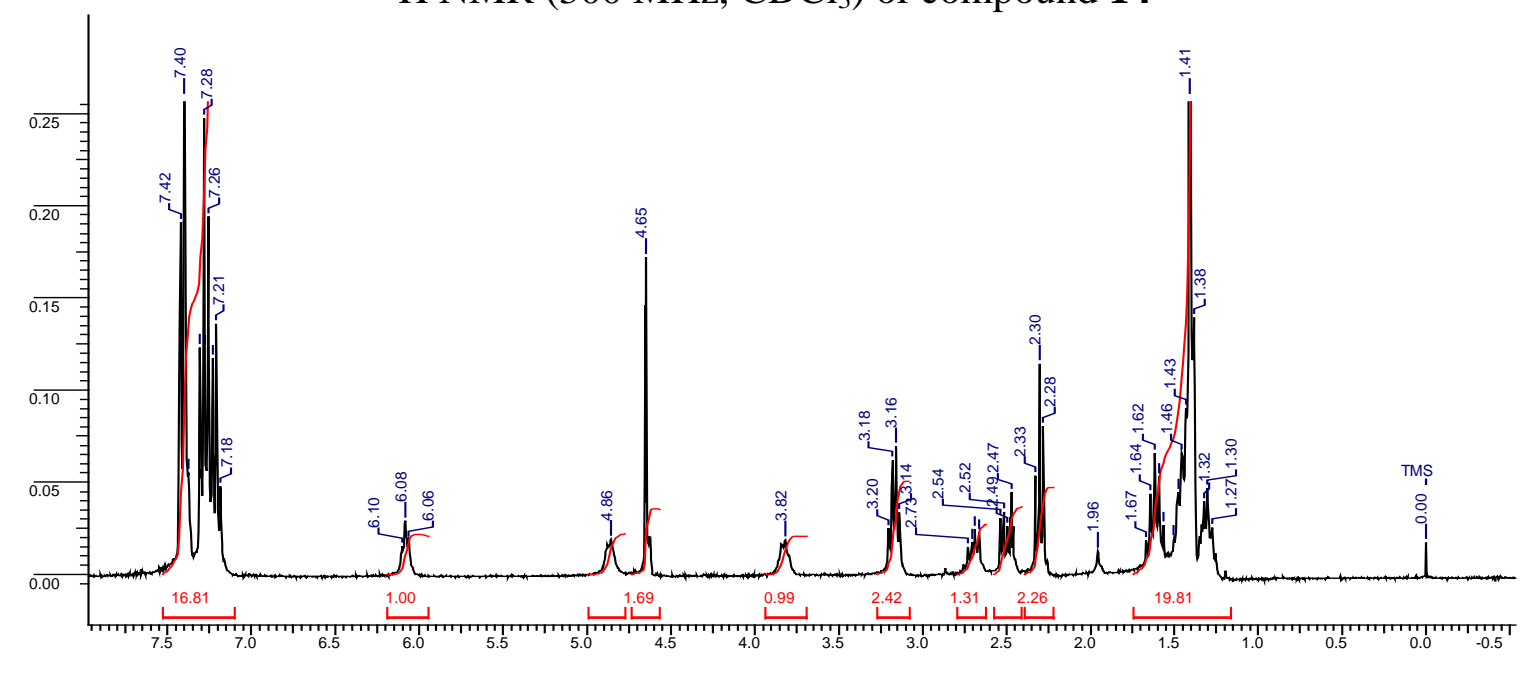

${ }^{13} \mathrm{C}$ NMR $\left(75 \mathrm{MHz}, \mathrm{CDCl}_{3}\right.$ ) of compound 14

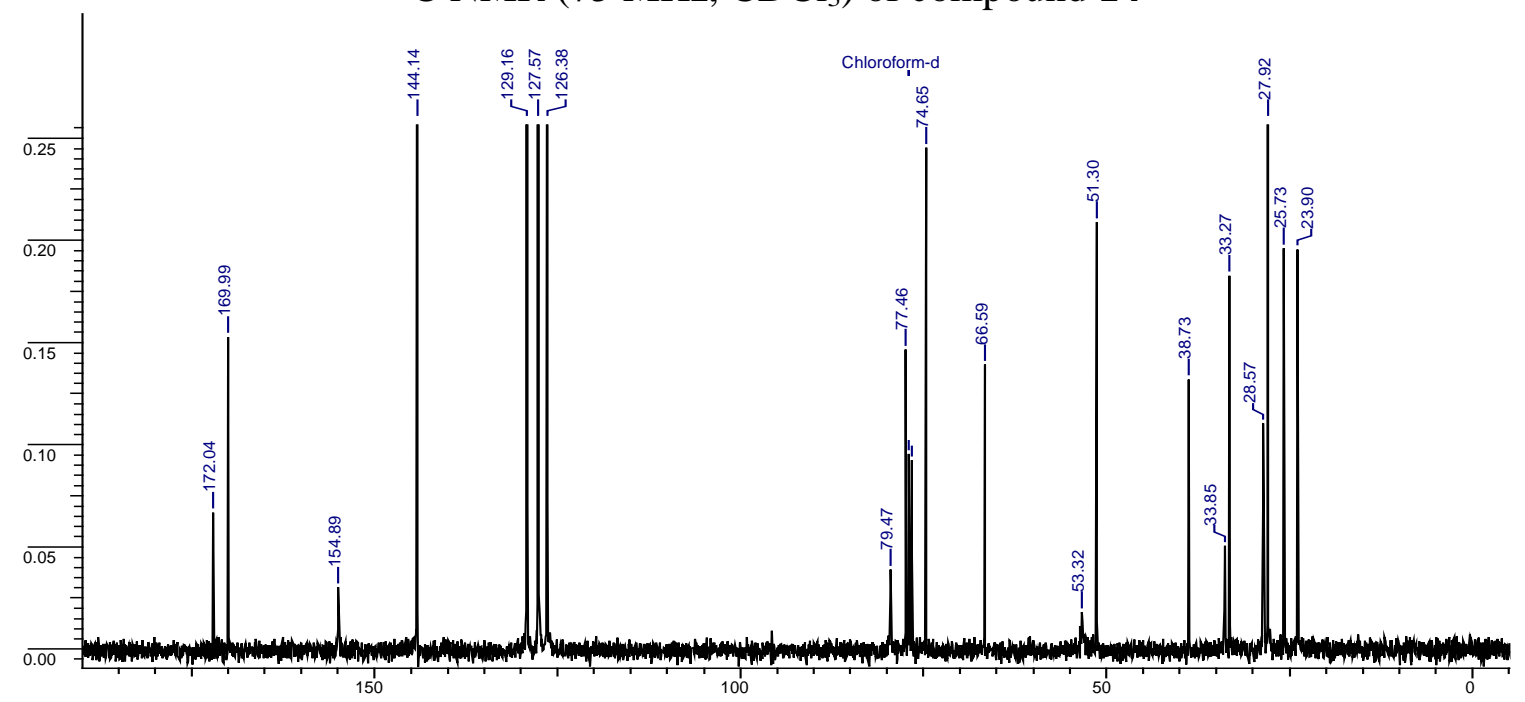

DEPT NMR (75 MHz, $\mathrm{CDCl}_{3}$ ) of compound 14

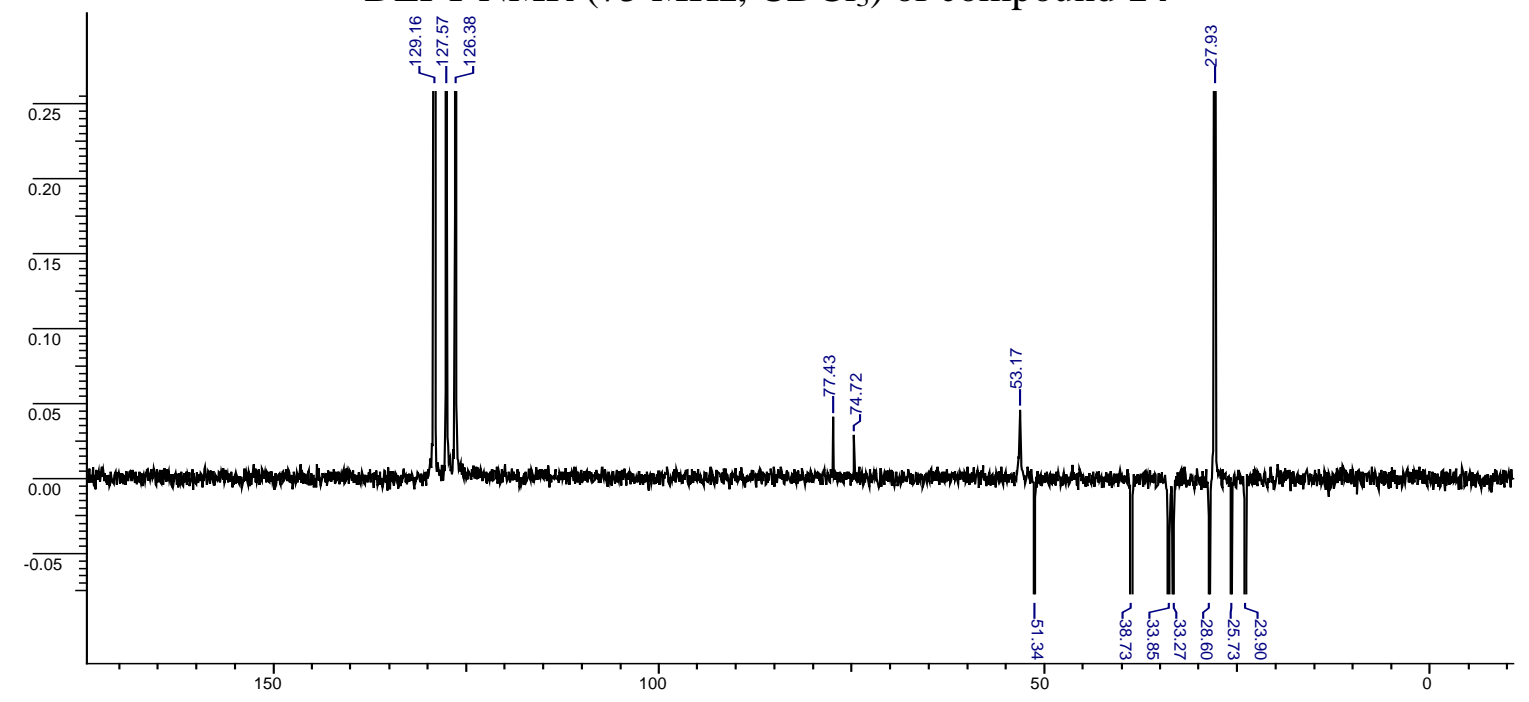


${ }^{1} \mathrm{H}$ NMR (200 MHz, $\mathrm{CDCl}_{3}$ ) of compound 15

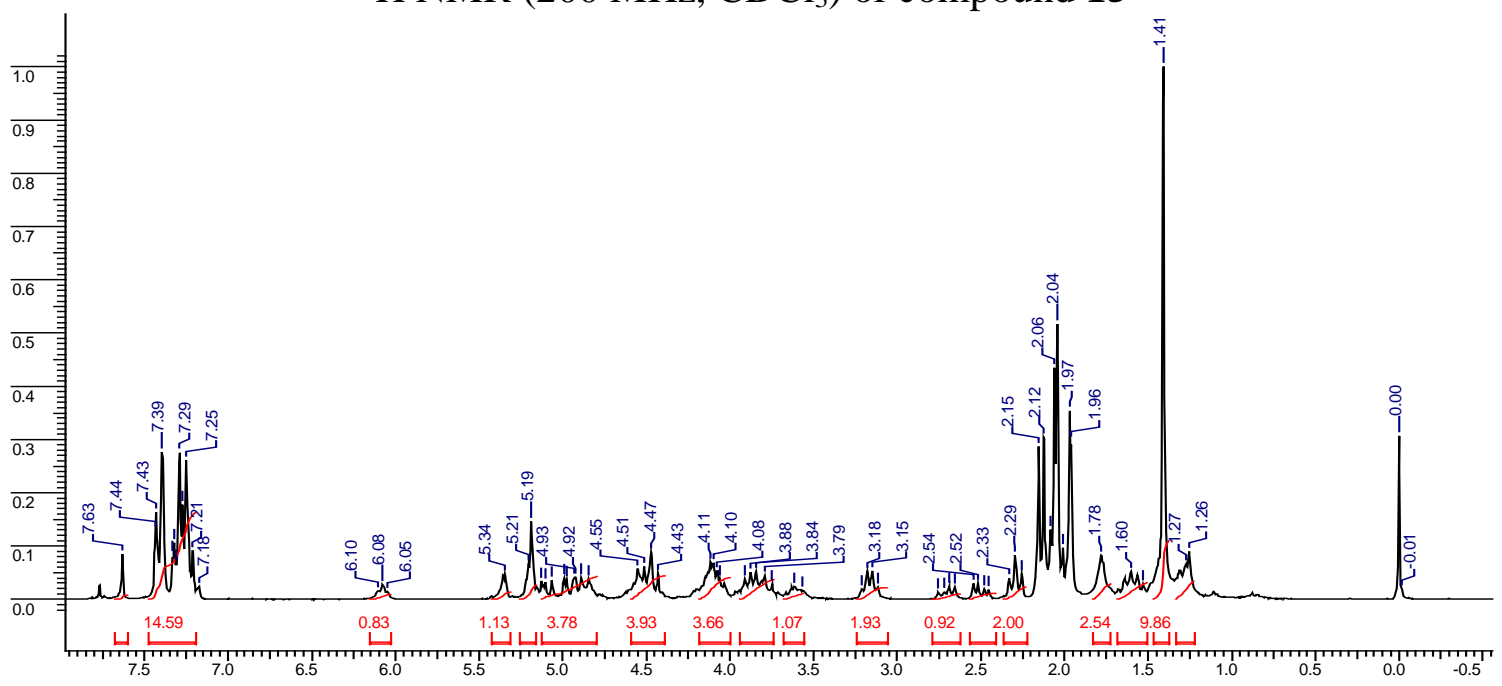

${ }^{13} \mathrm{C}$ NMR (50 MHz, $\mathrm{CDCl}_{3}$ ) of compound 15

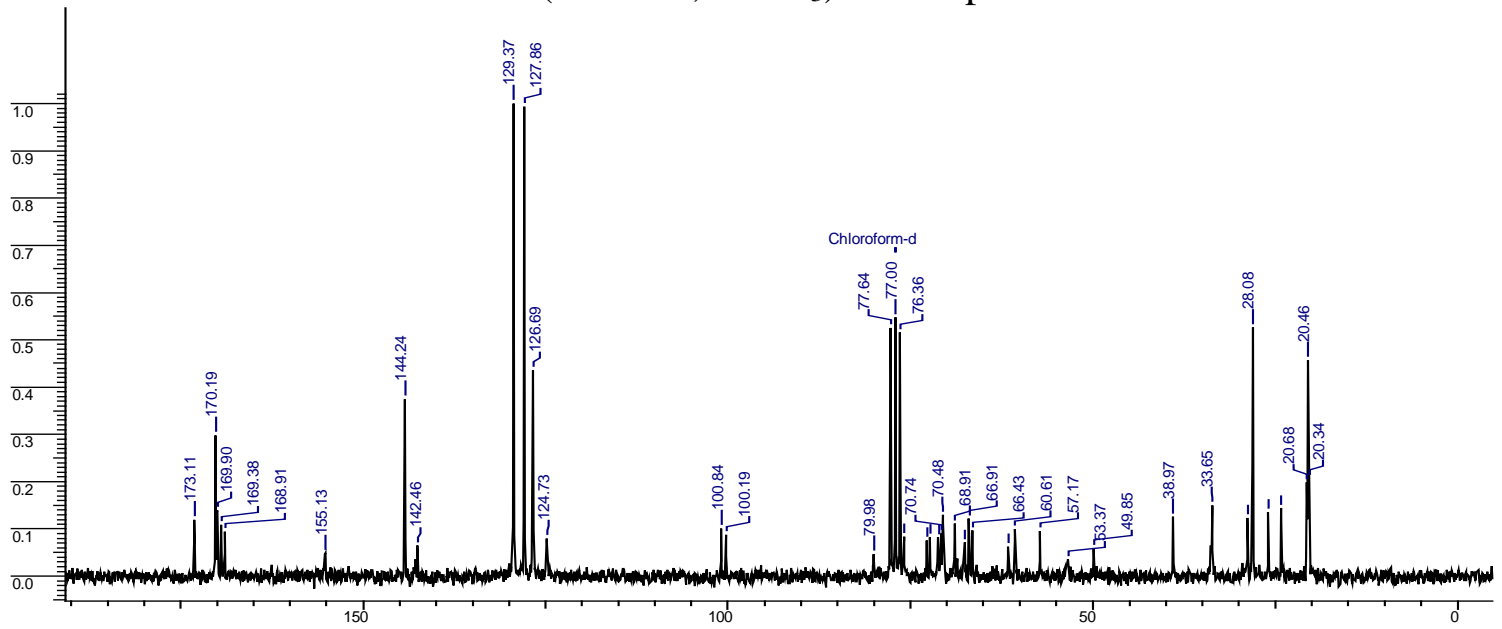

DEPT NMR (50 MHz, $\mathrm{CDCl}_{3}$ ) of compound 15

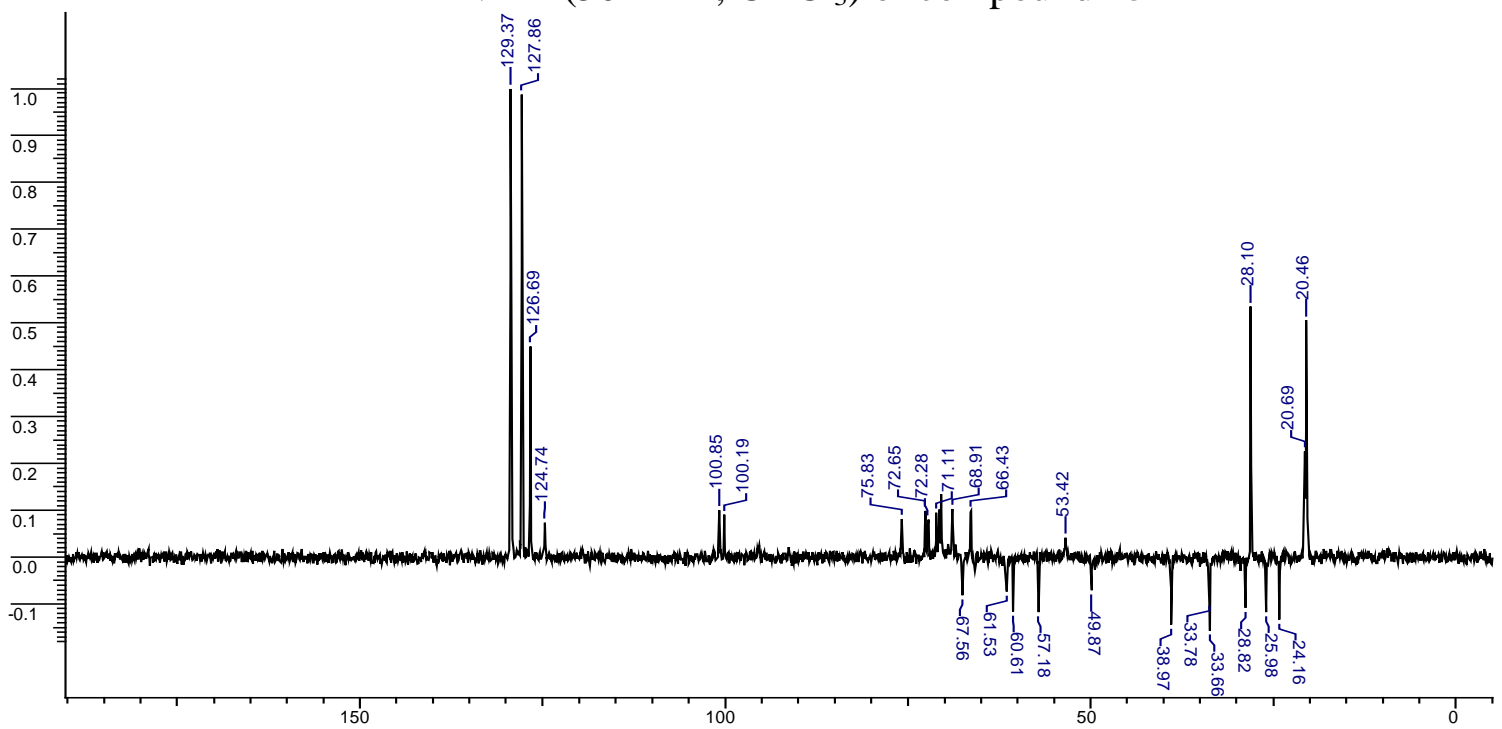




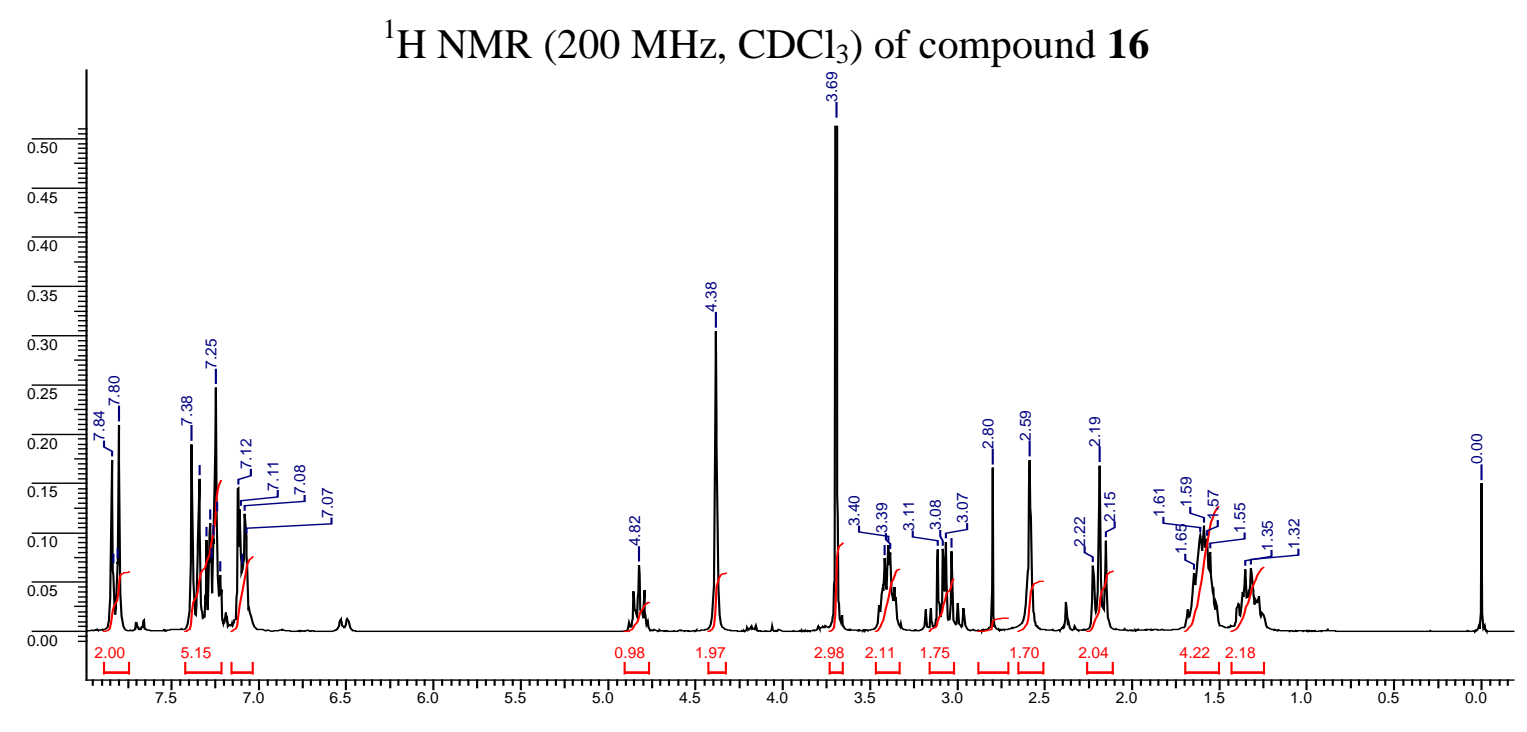

${ }^{13} \mathrm{C} \mathrm{NMR}\left(75 \mathrm{MHz}, \mathrm{CDCl}_{3}\right)$ of compound 16

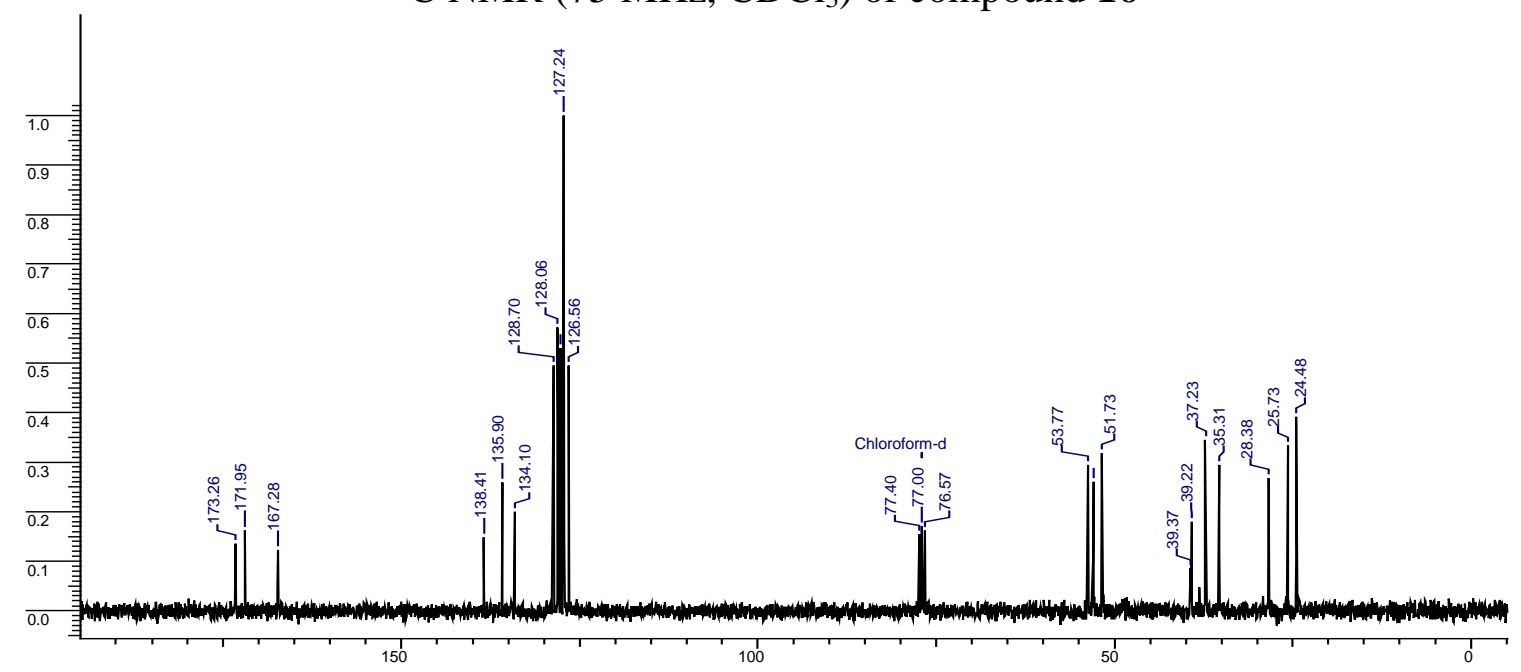

DEPT NMR (75 MHz, $\mathrm{CDCl}_{3}$ ) of compound 16

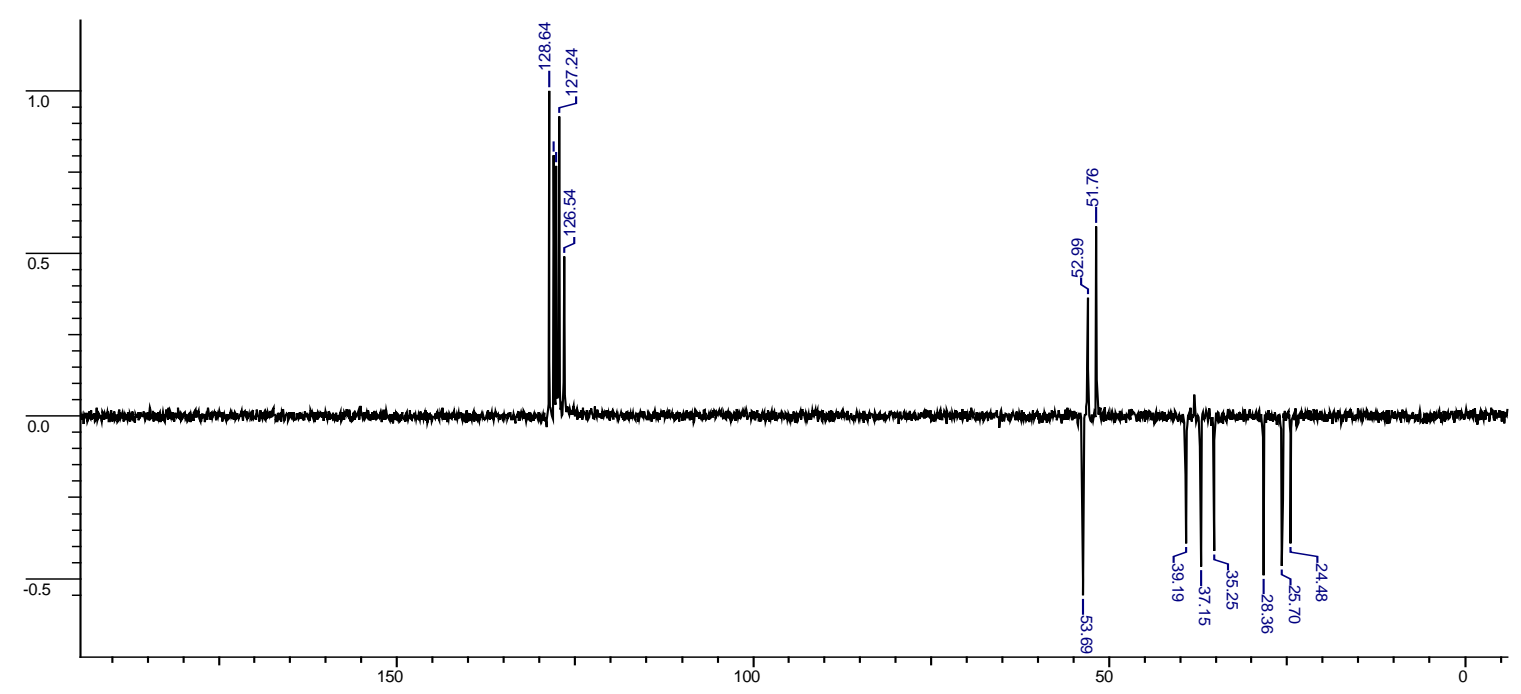



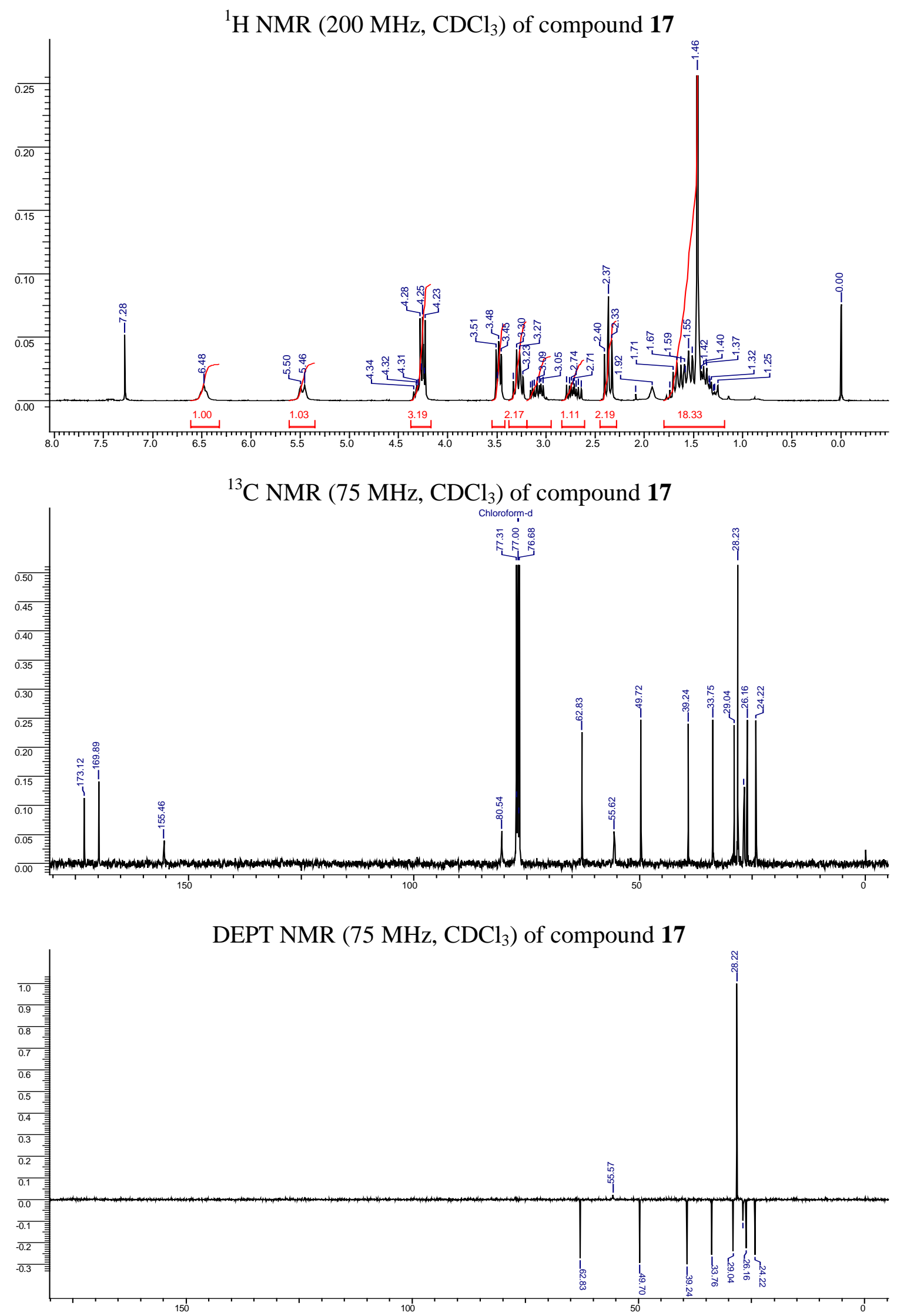
${ }^{1} \mathrm{H}$ NMR $\left(200 \mathrm{MHz}, \mathrm{CDCl}_{3}\right.$ ) of compound $\mathbf{1 8}$

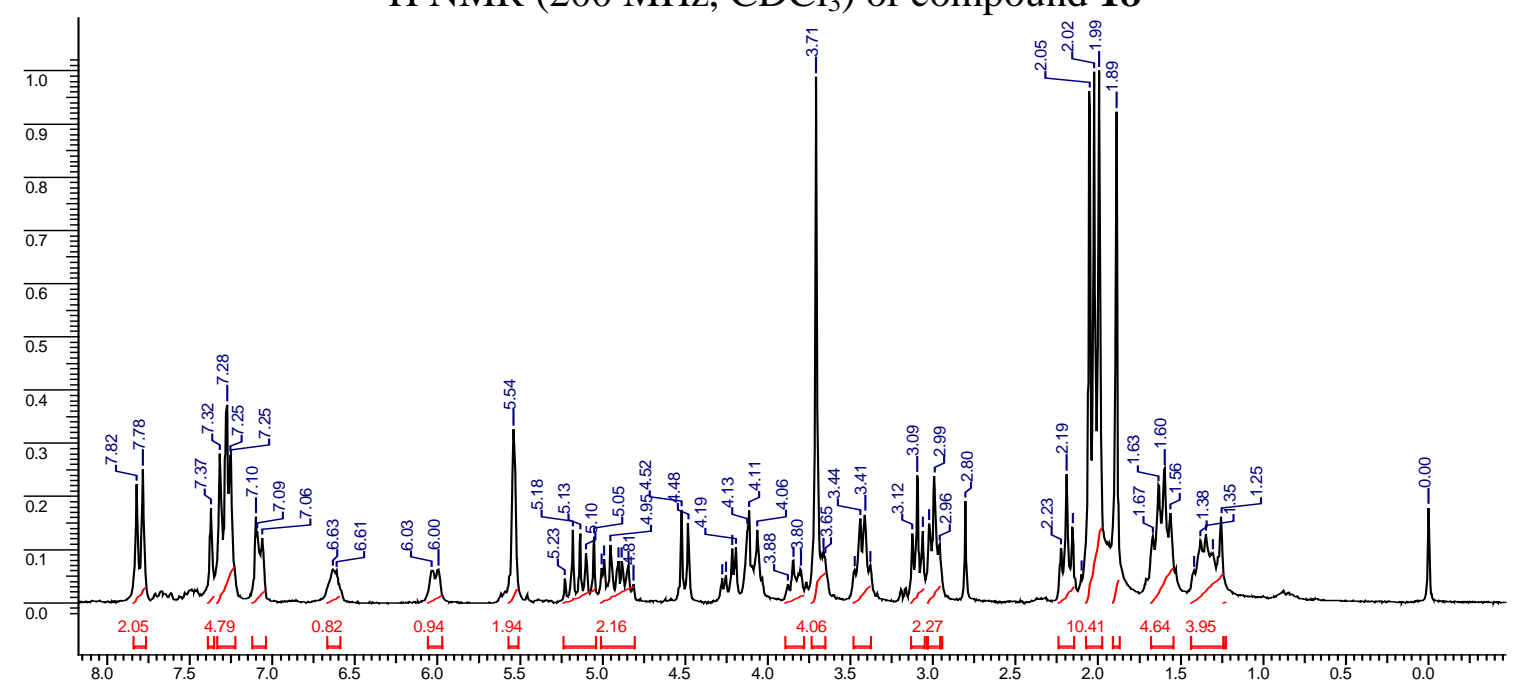

${ }^{13} \mathrm{C}$ NMR (50 MHz, $\mathrm{CDCl}_{3}$ ) of compound 18

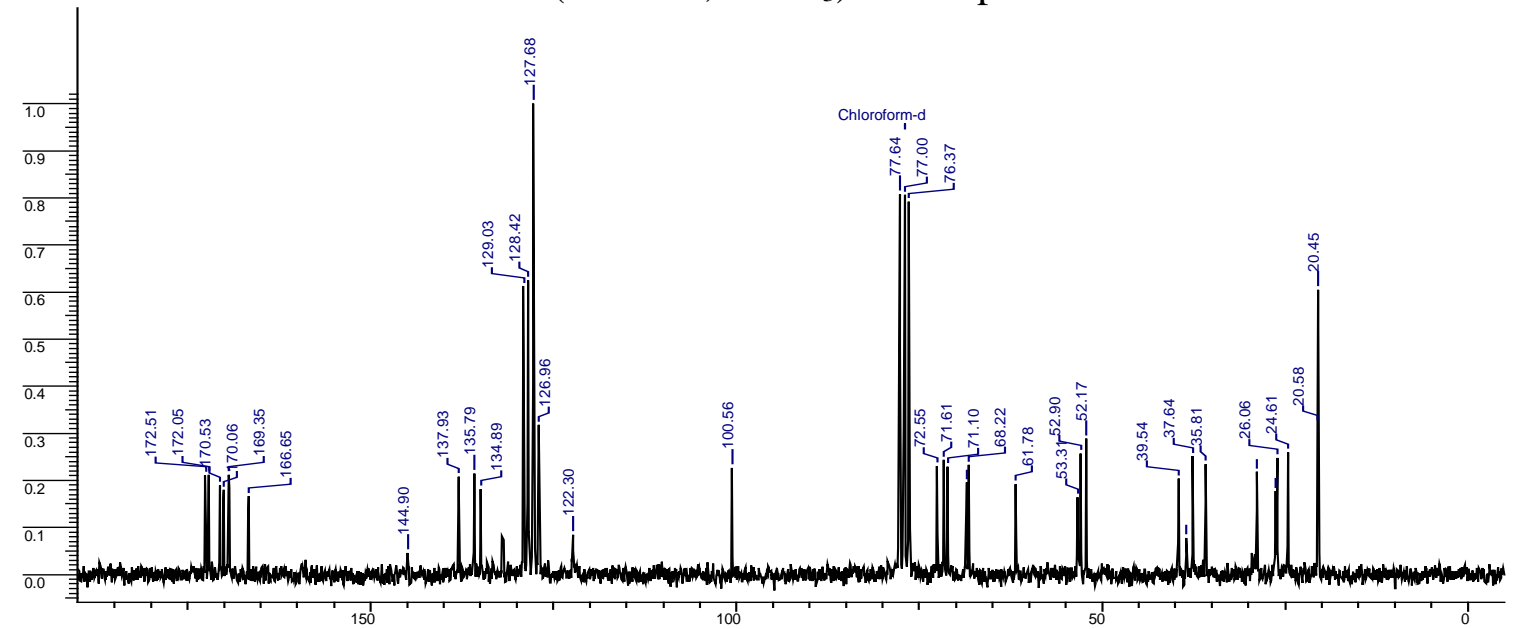

DEPT NMR (50 MHz, $\mathrm{CDCl}_{3}$ ) of compound $\mathbf{1 8}$

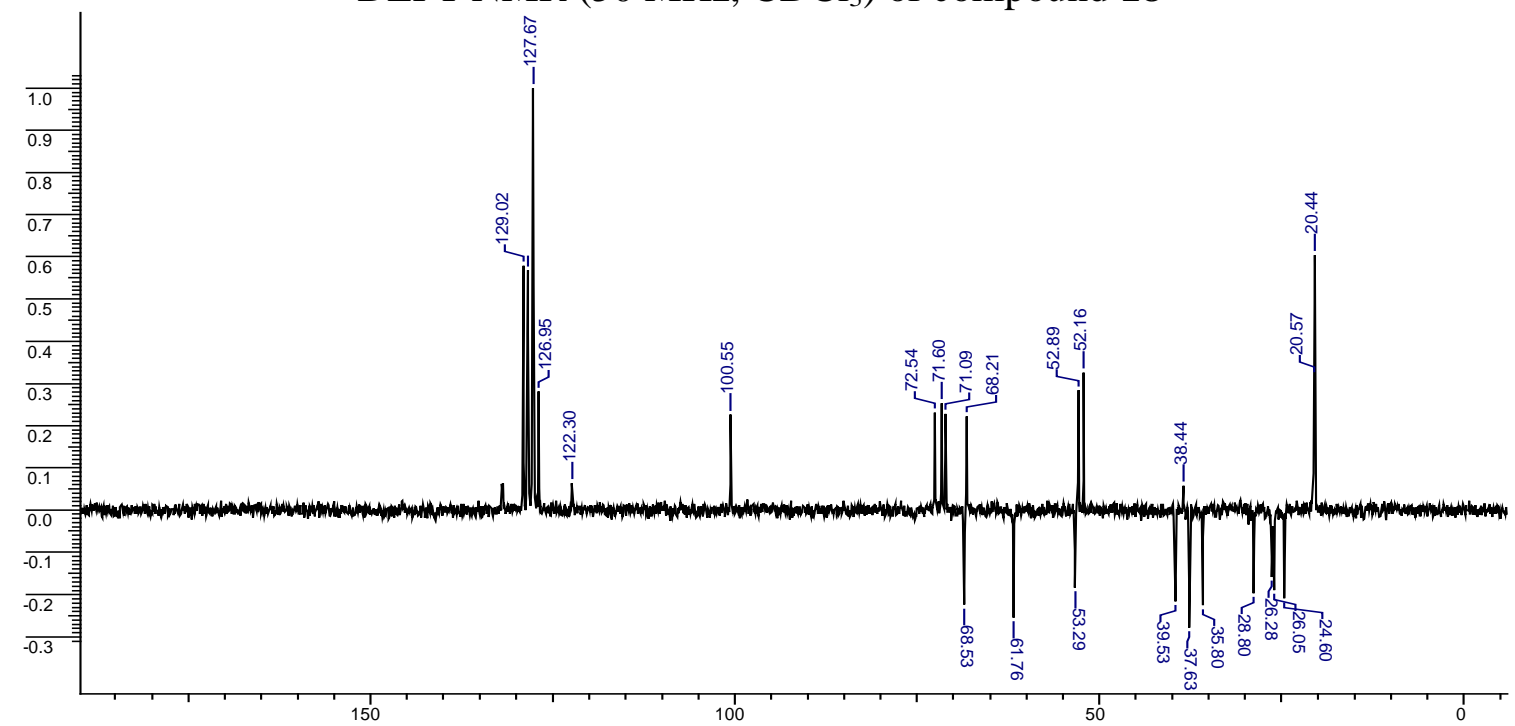


${ }^{1} \mathrm{H}$ NMR (200 MHz, $\mathrm{CDCl}_{3}$ ) of compound 19

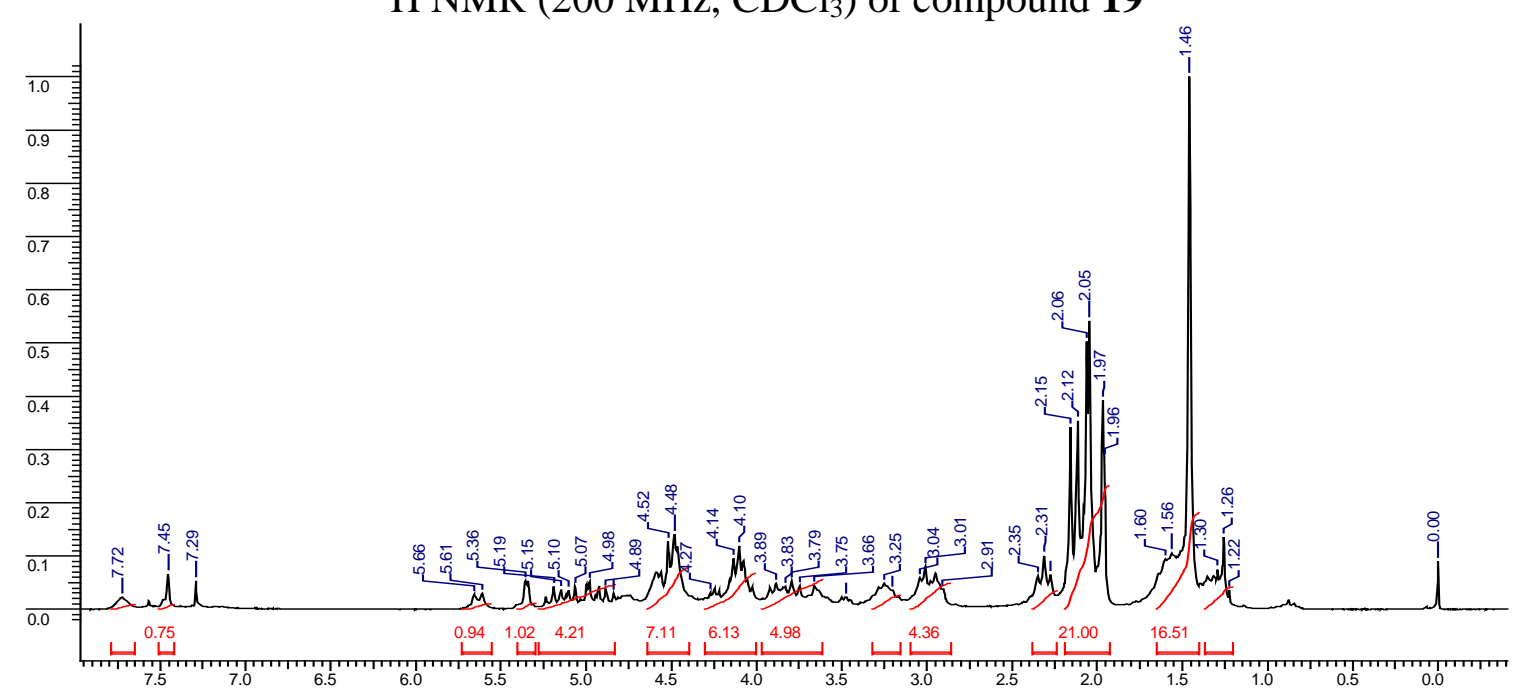

${ }^{13} \mathrm{C}$ NMR (50 MHz, $\mathrm{CDCl}_{3}$ ) of compound 19

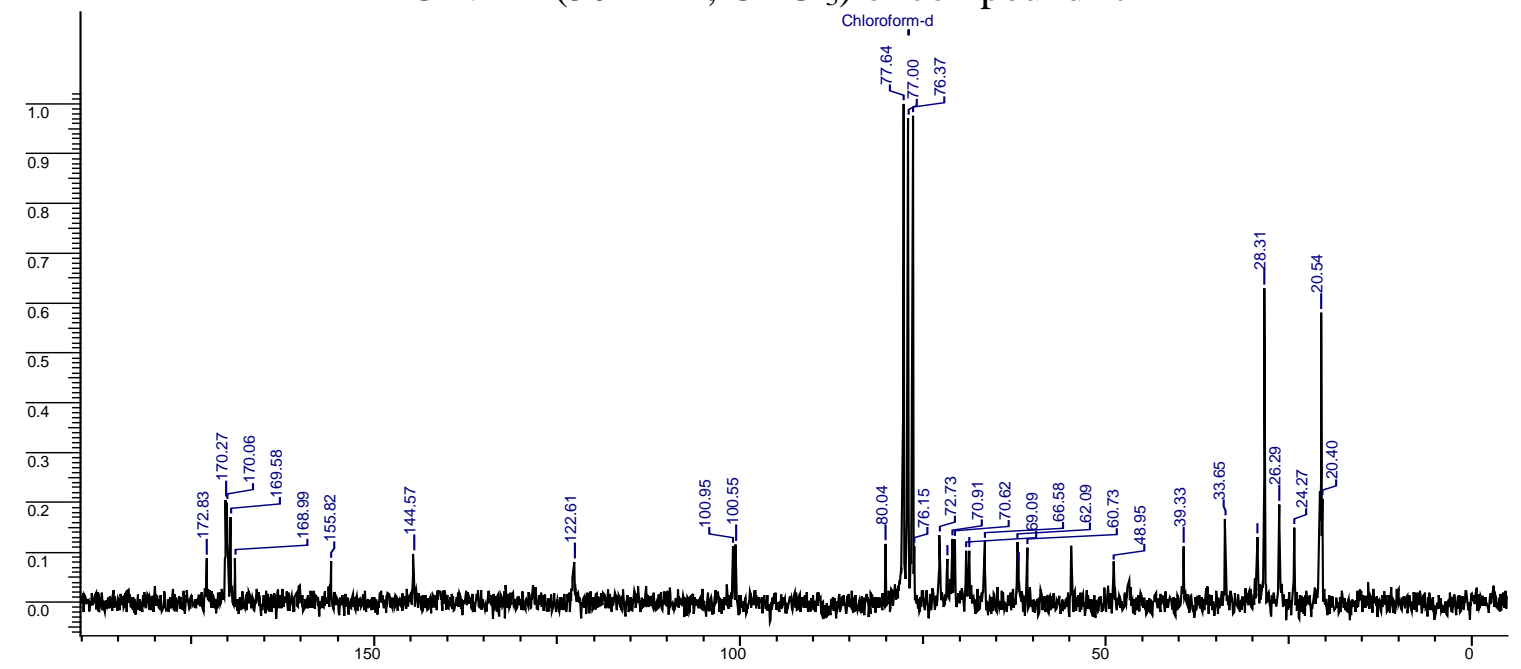

DEPT NMR (50 MHz, $\mathrm{CDCl}_{3}$ ) of compound 19

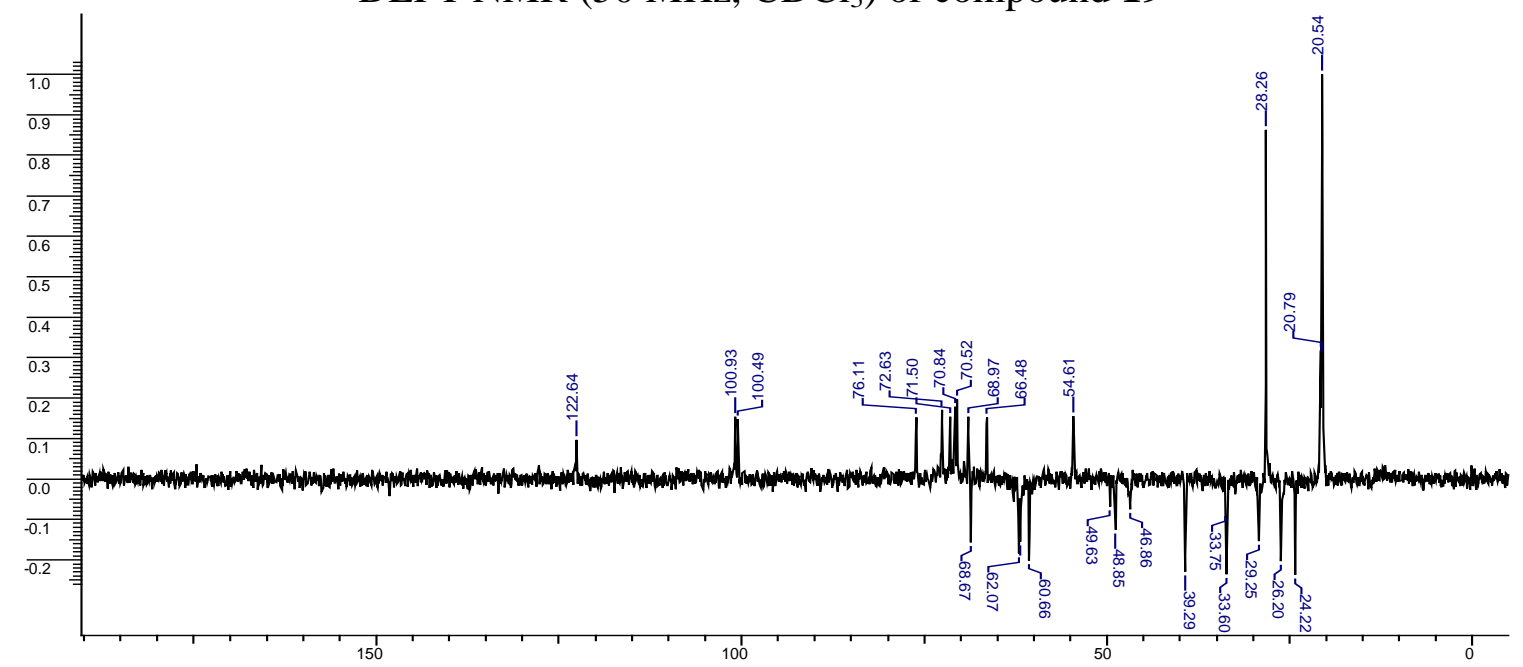


${ }^{1} \mathrm{H}$ NMR $\left(200 \mathrm{MHz}, \mathrm{CDCl}_{3}\right)$ of compound 20

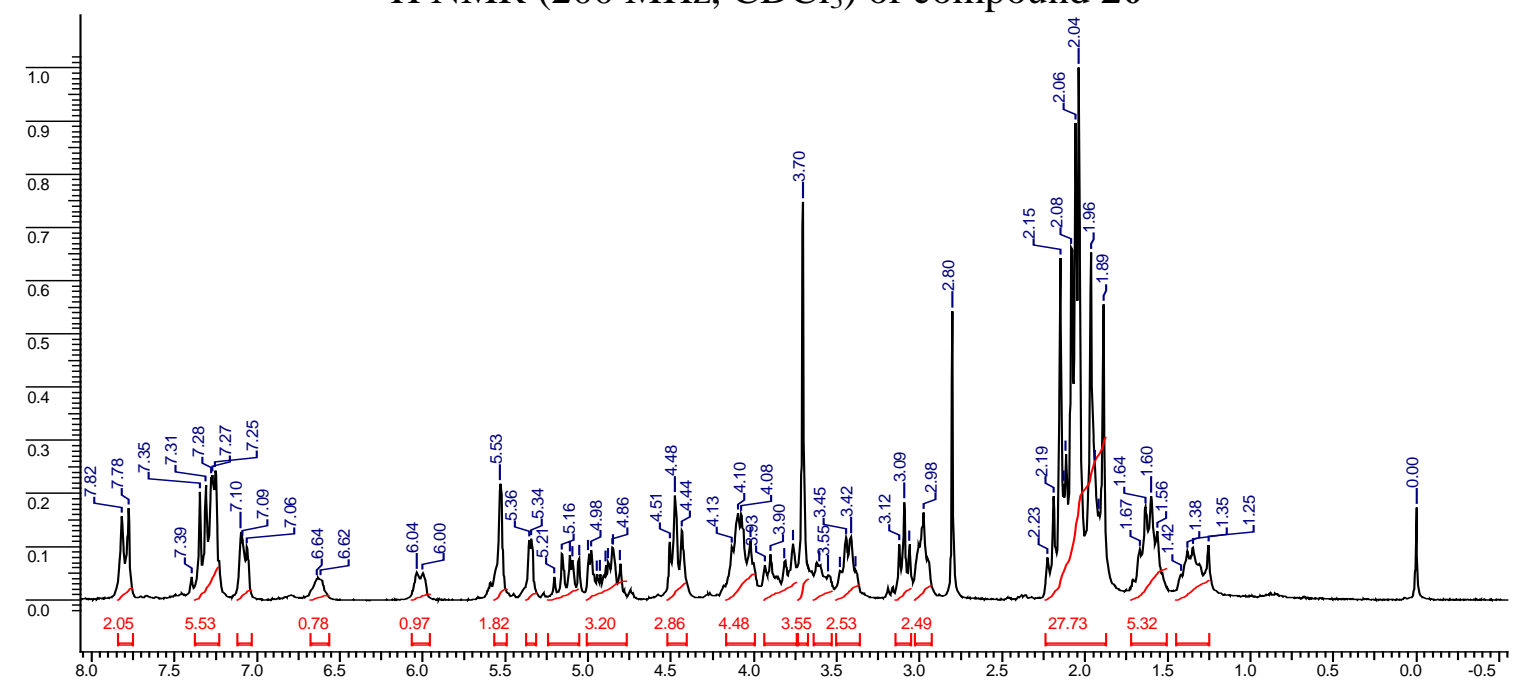

${ }^{13} \mathrm{C}$ NMR $\left(50 \mathrm{MHz}, \mathrm{CDCl}_{3}\right.$ ) of compound 20

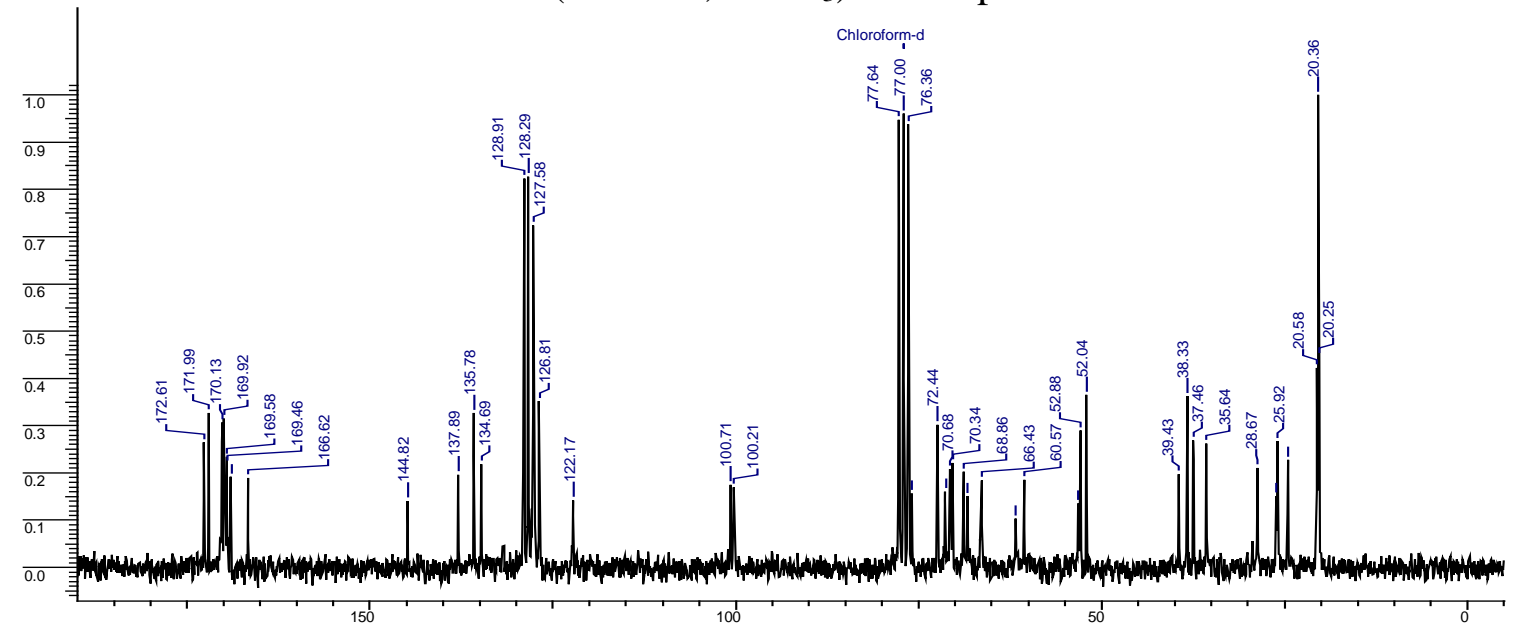

DEPT NMR (50 MHz, $\mathrm{CDCl}_{3}$ ) of compound 20

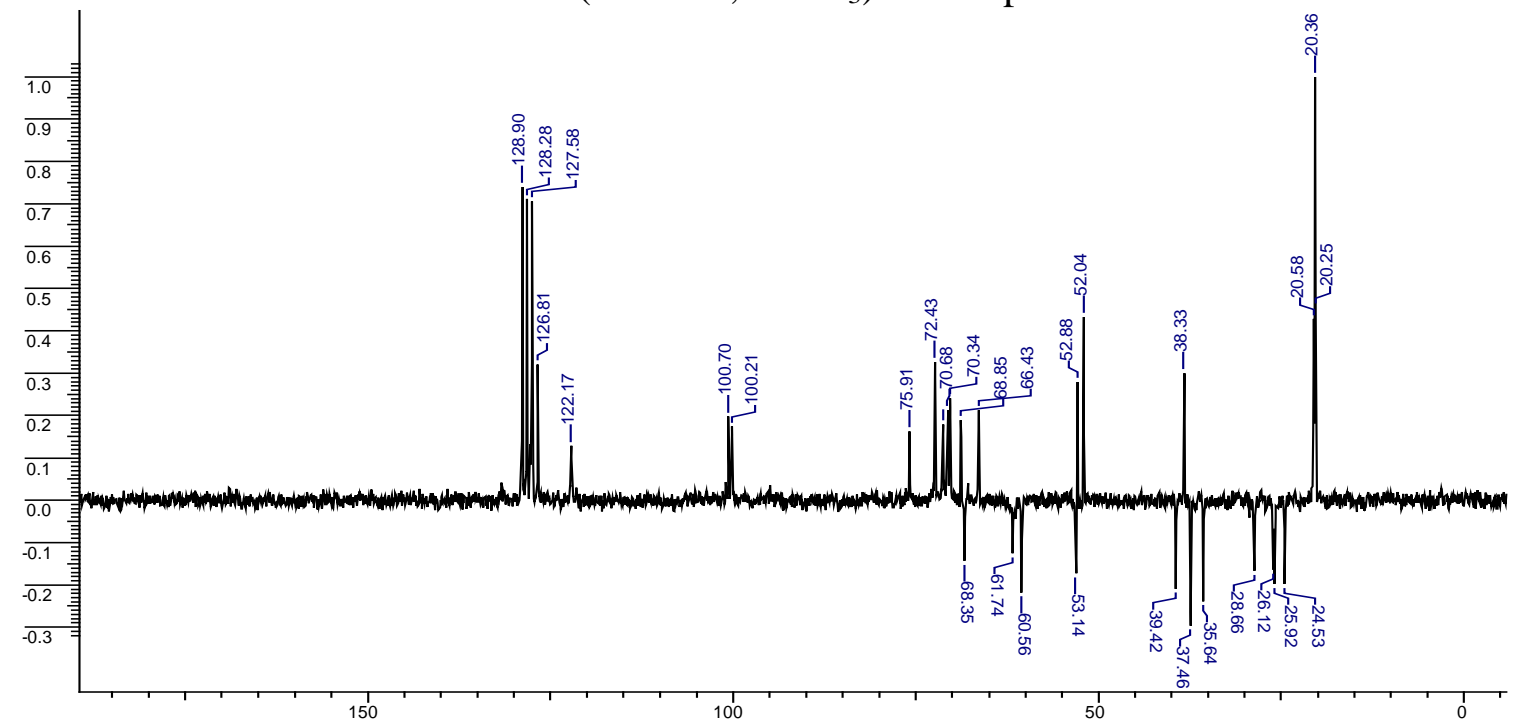


${ }^{1} \mathrm{H}$ NMR $\left(200 \mathrm{MHz}, \mathrm{CDCl}_{3}\right.$ ) of compound 21

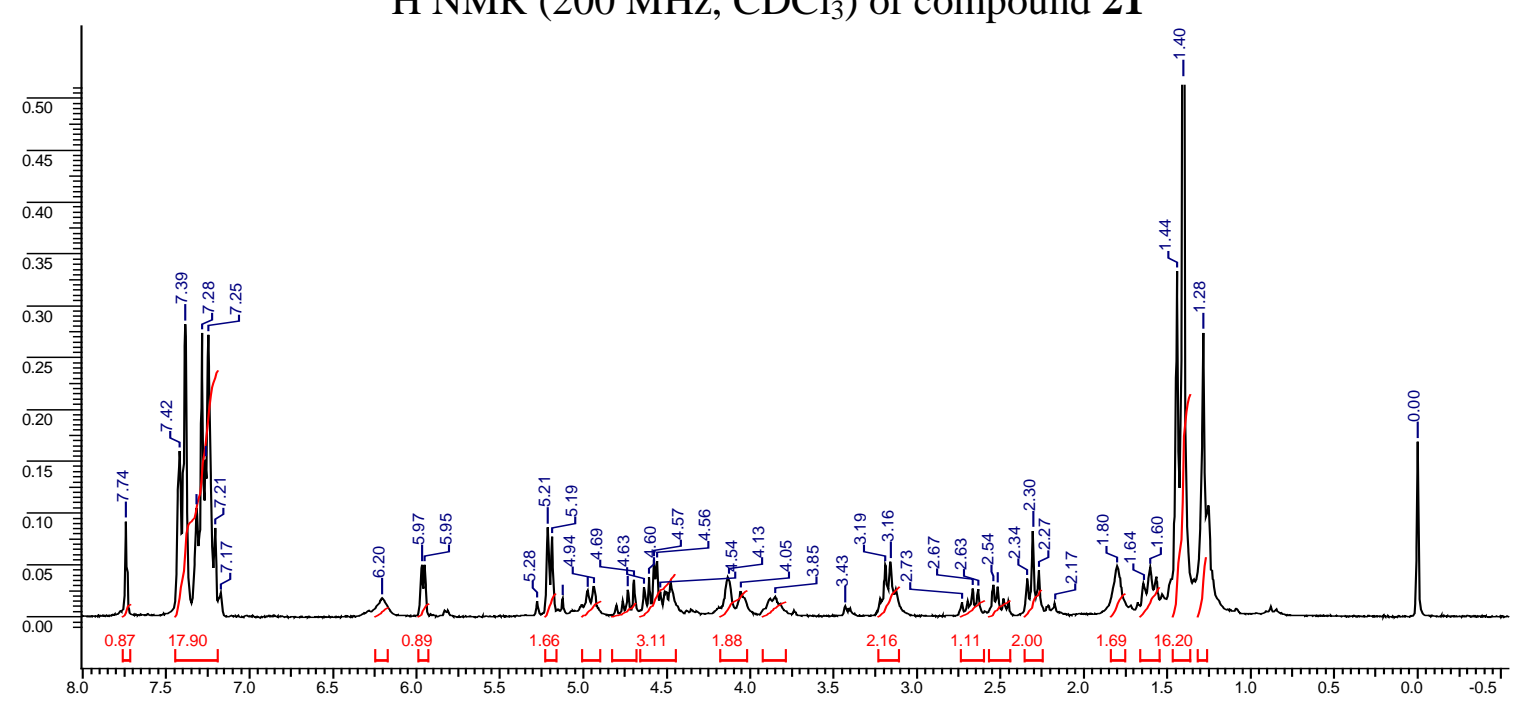

${ }^{13} \mathrm{C}$ NMR $\left(50 \mathrm{MHz}, \mathrm{CDCl}_{3}\right.$ ) of compound 21

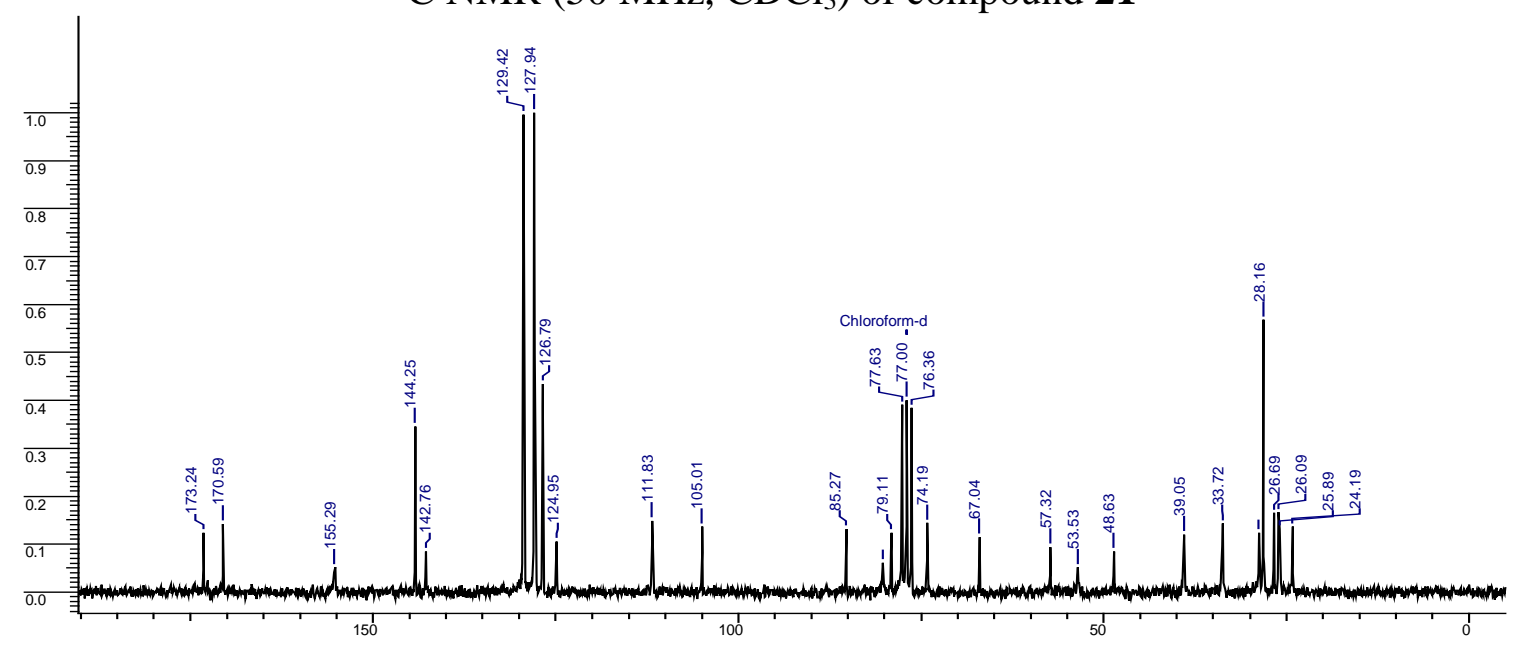

DEPT NMR (50 MHz, $\mathrm{CDCl}_{3}$ ) of compound 21

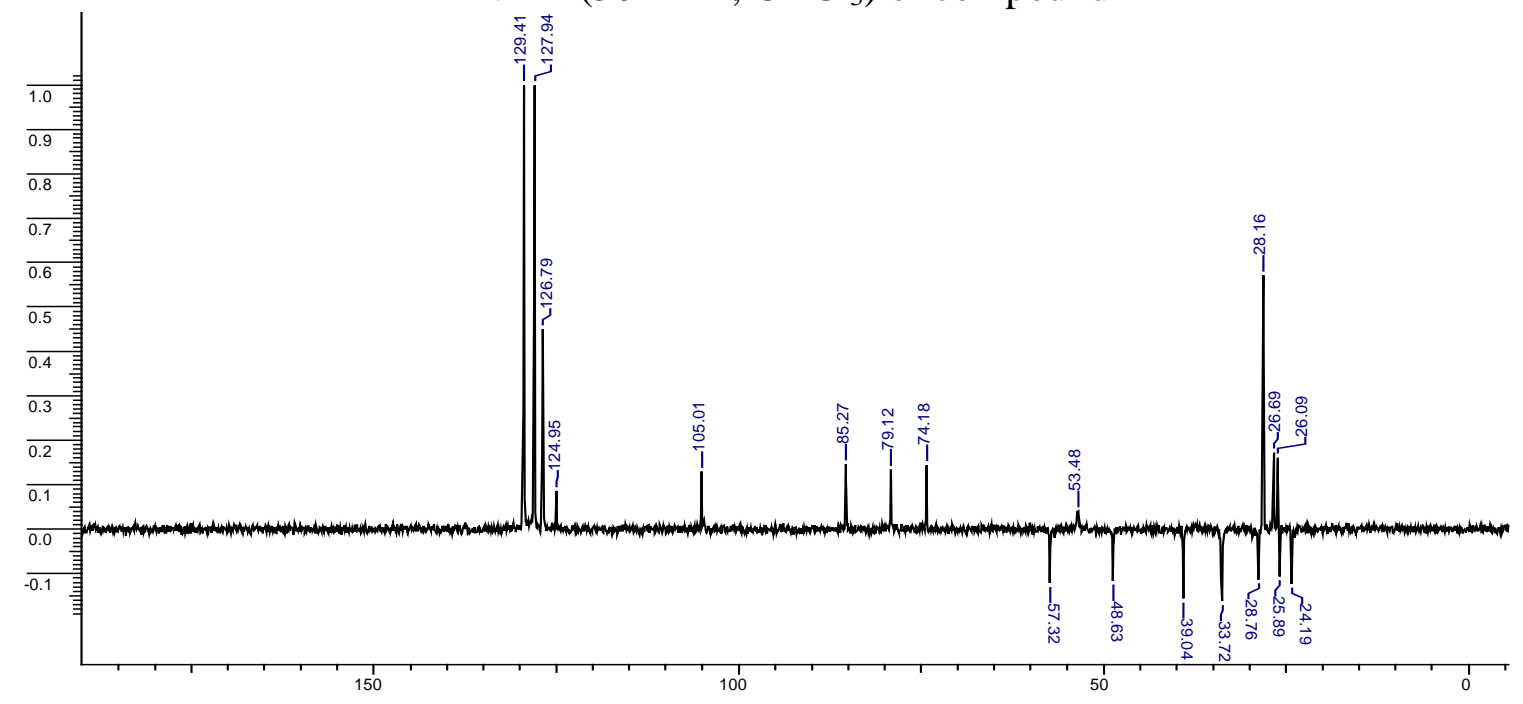

